\title{
Molecular Engineering of Functional Materials for Energy and Opto-Electronic Applications
}

\author{
Peng Gao, Domanski Konrad, Sadig Aghazada, and Mohammad Khaja Nazeeruddin*
}

\begin{abstract}
This review presents an overview of the dedicated research directions of the Group for Molecular Engineering of Functional Materials (GMF). This includes molecular engineering aspects of sensitizers constructed from ruthenium complexes, organic molecules, porphyrins and phthalocyanines. Manipulation of organometal trihalide perovskites, and charge transporting materials for high performance perovskite solar cells and photo-detectors are also described. Controlling phosphorescence color, and quantum yields in iridium complexes by tailoring ligands for organic light emitting diodes are demonstrated. Efficient reduction of $\mathrm{CO}_{2}$ to $\mathrm{CO}$ using molecular catalyst on a protected $\mathrm{Cu}_{2} \mathrm{O}$ photocathode, and cost-effective water-splitting cell using a high efficiency perovskite solar cell are presented.
\end{abstract}

Keywords: Dye · Functional materials · Molecular engineering $\cdot$ Perovskite

\section{Introduction}

Molecular engineering of functional materials specifically tailored to address the present energy and environmental issues has witnessed a well-deserved surge of attention. The synthesis of materials with tailored properties should be engineered at molecular level to achieve desired properties in the final devices. Therefore the research on advanced functional materials needs an interdisciplinary approach involving different expertise (organic, organo-metallic, inorganic, nano and physical approaches) and many techniques for characterization of the physical and chemical properties. In this article, we discuss our group's dedicated directions in molecular engineering of functional materials for energy and opto-electronic devices (Fig. 1).

The group is actively pursuing:

- Perovskite solar cells

- Molecular engineering of sensitizers for energy generation and OLED applications

- Charge transporting materials

- Metal oxide nanomaterials

- $\mathrm{CO}_{2}$ reduction

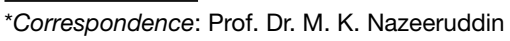
Group for Molecular Engineering of Functional Materials

Institute of Chemical Sciences and Engineering-Valais Swiss Federal Institute of Technology EPFL

$\mathrm{CH}-1015$ Lausanne

E-mail: mdkhaja.nazeeruddin@epfl.ch
Based on the functional materials developed in the group, we have fabricated dye-sensitized solar cells, perovskite solar cells, photodetectors, organic light-emitting diodes and solar fuels. At the EPFLValais campus, with the cooperation between synthetic and device fabrication teams, we will continue to push the limits to address to energy and environmental issues.

Harvesting energy from sunlight using photovoltaic technology at low cost is a way to address the energy demands of the growing global population. Solar power is one of the best renewable energy resources that can minimize the detrimental effects of human activity on the environment without increasing atmospheric emissions. In this respect dye-sensitized and perovskite solar cells have advantages due to their low cost, ease of processing and flexibility. Additionally, the materials employed are abundantly available, which is very important in the advancement of new generations of non-silicon based light harvesting devices (dye-sensitized solar cells or perovskite solar cells) for many years. It is the ever-increasing photon-to-current conversion ability of the new functional materials that will change the energy production and distribution system where the energy consumer will become a producer.

\section{Sensitizers for Dye-sensitized Solar Cells (DSSCs)}

The schematic explanation of the operating principles of a dye-sensitized solar cell is shown in Fig. 2. One of the essential components in the device is the sensitizer adsorbed onto a mesoporous $\mathrm{TiO}_{2}$ oxide

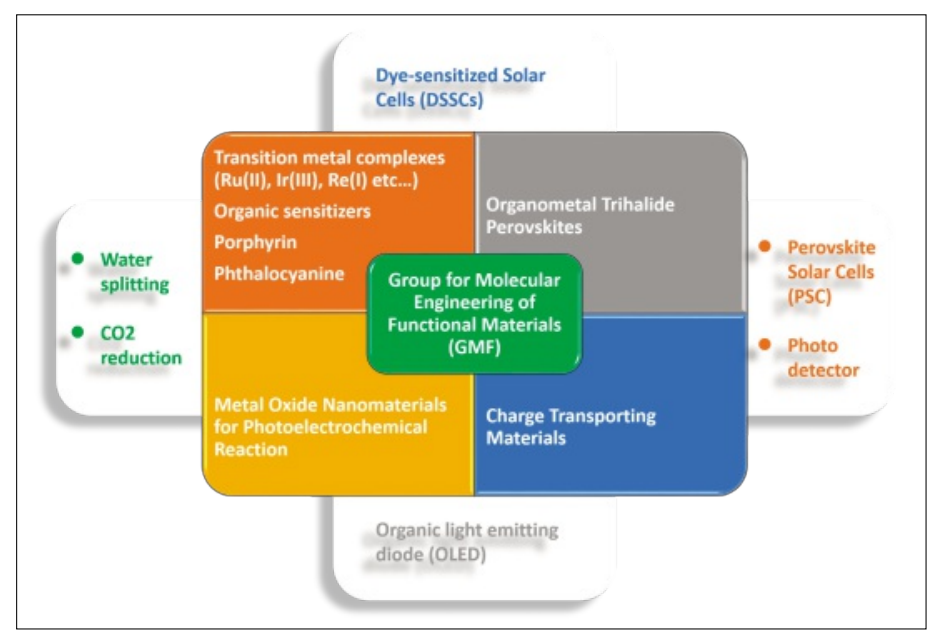

Fig. 1.

Mission of GMF. 


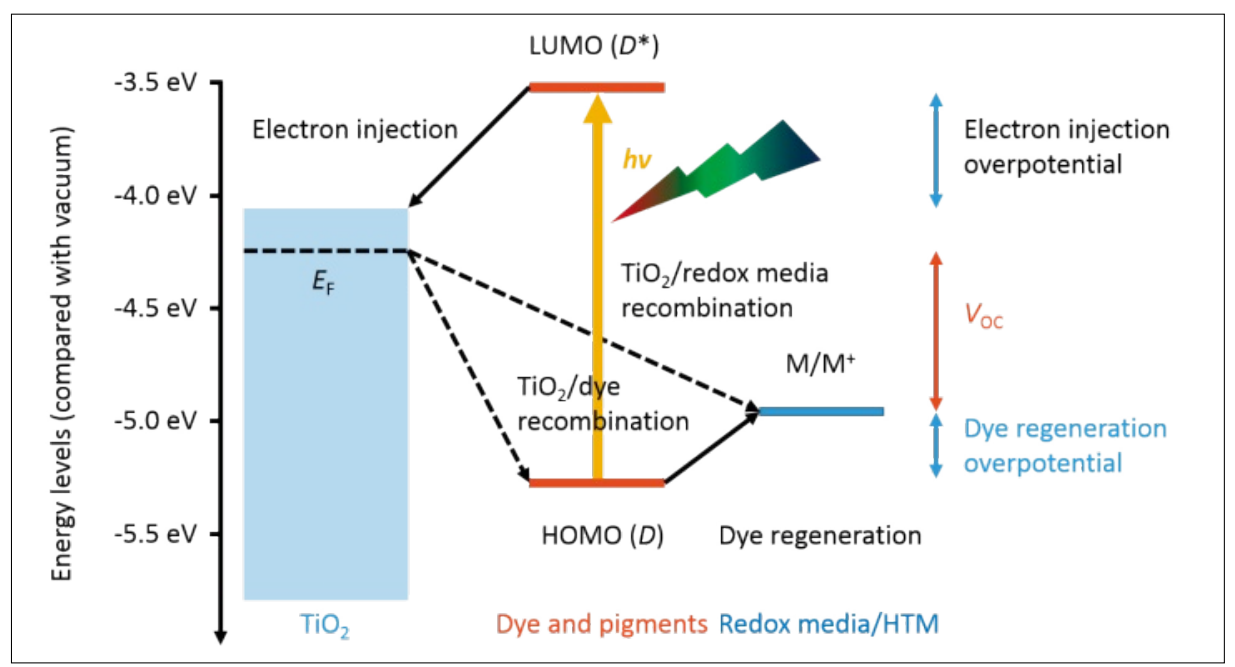

Fig. 2. Energy diagram and operating principle of a dye-sensitized solar cell.

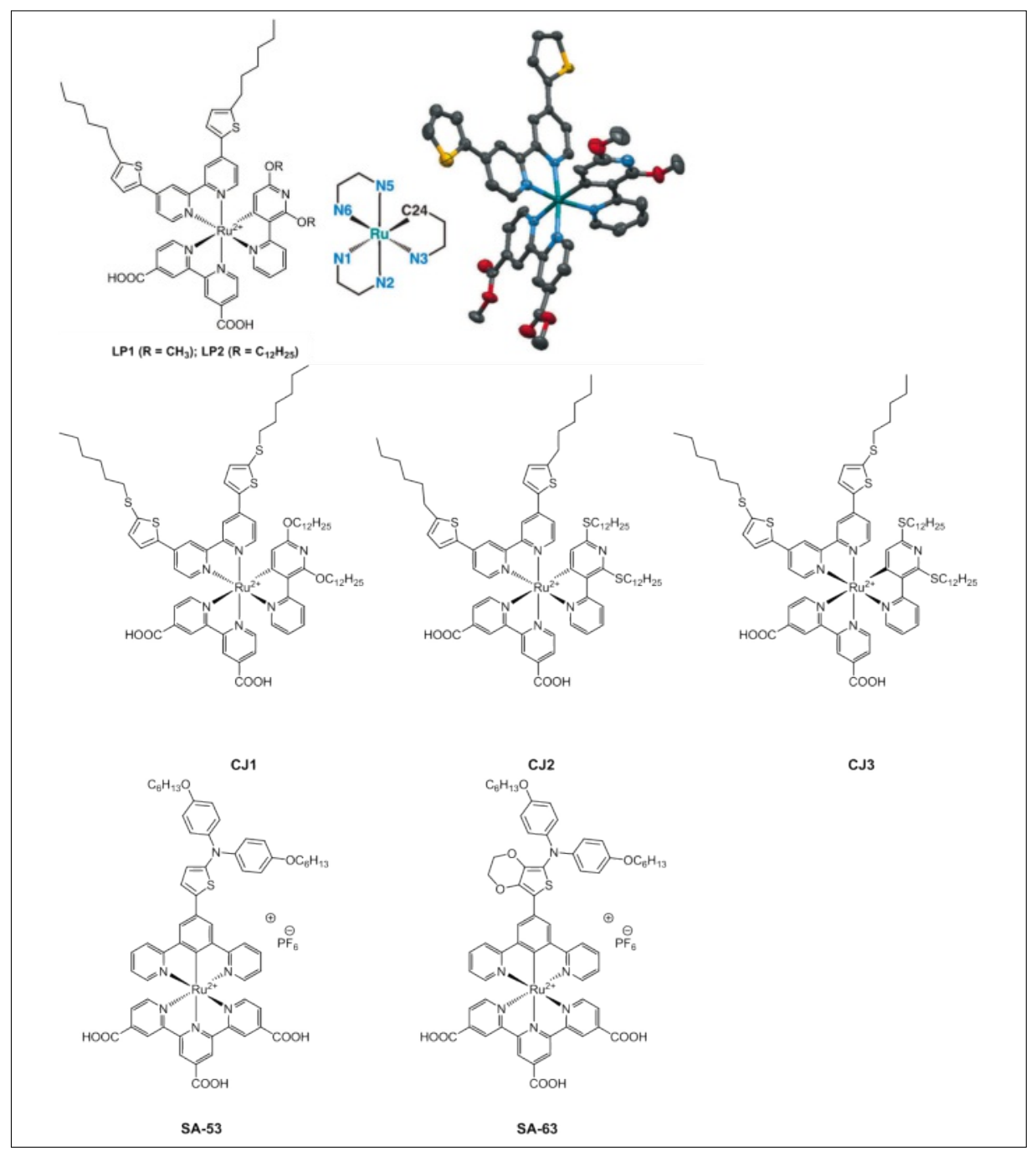

Fig. 3. Structures of LP1, LP2, CJ1, CJ2, CJ3, SA-53 and SA-63. Crystal structure of LP1. $2 \mathrm{CH}_{2} \mathrm{Cl}_{2}$. Thermal ellipsoids are drawn at the $50 \%$ probability level. $\mathrm{N}$ blue, $\mathrm{O}$ red, $\mathrm{S}$ yellow, $\mathrm{Ru}$ turquoise.

layer. The photo-excitation of the sensitizer results in electron injection into the conduction band of the metal oxide. The oxidized sensitizer is successively reduced by electron donation from an electrolyte, containing either a liquid-based redox sys- tem (iodide/triiodide or $\mathrm{Co}^{(\mathrm{II})} / \mathrm{Co}^{(\mathrm{III})}$ ), or a solid-state organic p-type semiconductor. The injected electron streams through the semiconductor nanoparticle network to arrive at the back contact and then through the external load to the counter electrode.
At the counter electrode, reduction of oxidized redox mediator in turn regenerates its reduced form to complete the circuit.

\subsection{Ruthenium Sensitizers}

Among the transition metal complexes, ruthenium polypyridyl complexes are well suited due to their stability and tunable optical properties by incorporating functional ligands. In addition, the ruthenium octahedral complexes exhibit several stable oxidation states and are photochemically robust, undergoing several millions of redox cycles. ${ }^{[1]}$ Representative examples of functionalized ruthenium sensitizers developed in our laboratory are shown in Fig. 3.

We have designed and synthesized two multifunctional cyclometallated ruthenium dyes (LP1 and LP2) (Fig. 3) aiming at improving the compatibility of these dyes with a cobalt electrolyte system. ${ }^{2]}$ The tailored ligand, 2',6'-dimethoxy-2,3'-bipyridine is convenient to tune the HOMO energy level of the metal $\mathrm{t} 2$, orbitals. The incorporated alkoxy substituents insulate the $\mathrm{TiO}_{2}$ surface through the alkyl chains. The ligand 2,2'-bis(5-hexylthiophen-2-yl)-2,2'-bipyridine improves

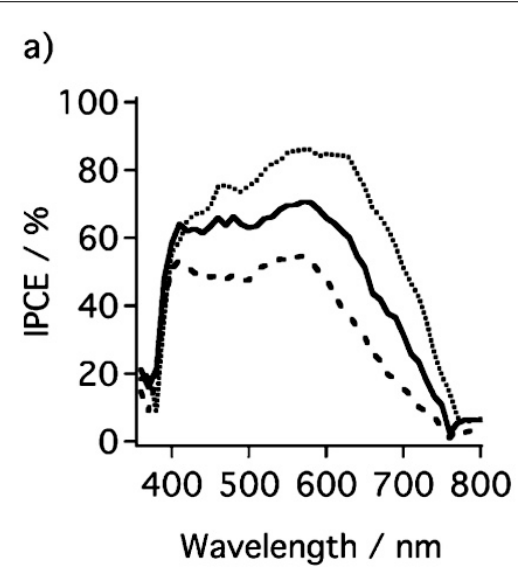

b)

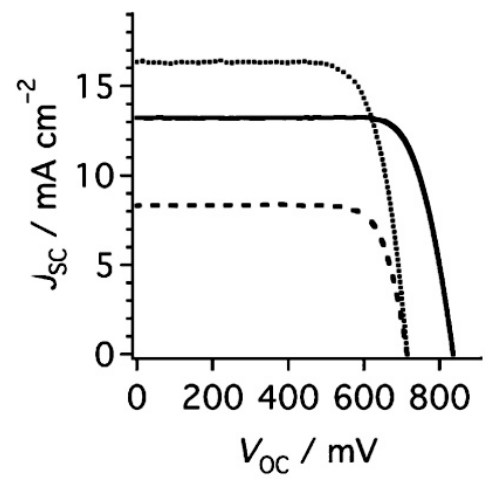

Fig. 4. (a) Photocurrent response spectra in mesoscopic solar cells, and (b) $J-V$ characteristics measured under simulated AM1.5 G full sun illumination $\left(100 \mathrm{mWcm}^{-2}\right)$ for devices employing LP1 and LP2. LP1 + cobalt (dashed line), LP2 + cobalt (solid line), LP2 + iodine (dotted line). 


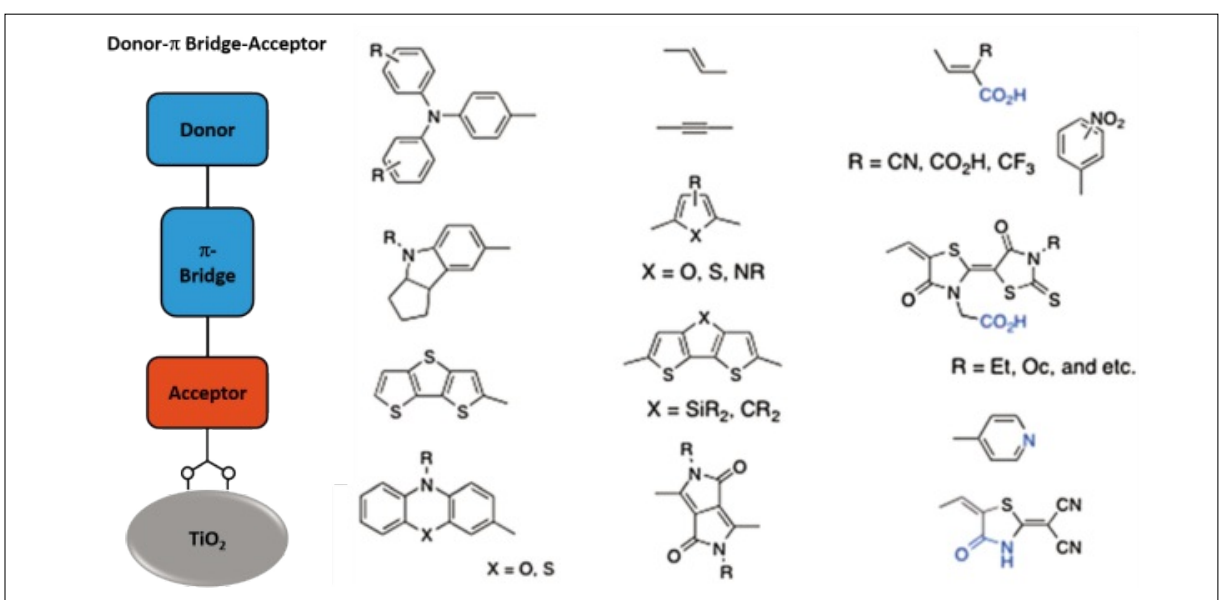

Fig. 5. Schematic drawing of $D-\pi-A$ type organic dye and examples of the donor, $\pi$-spacer and acceptor with anchoring components.

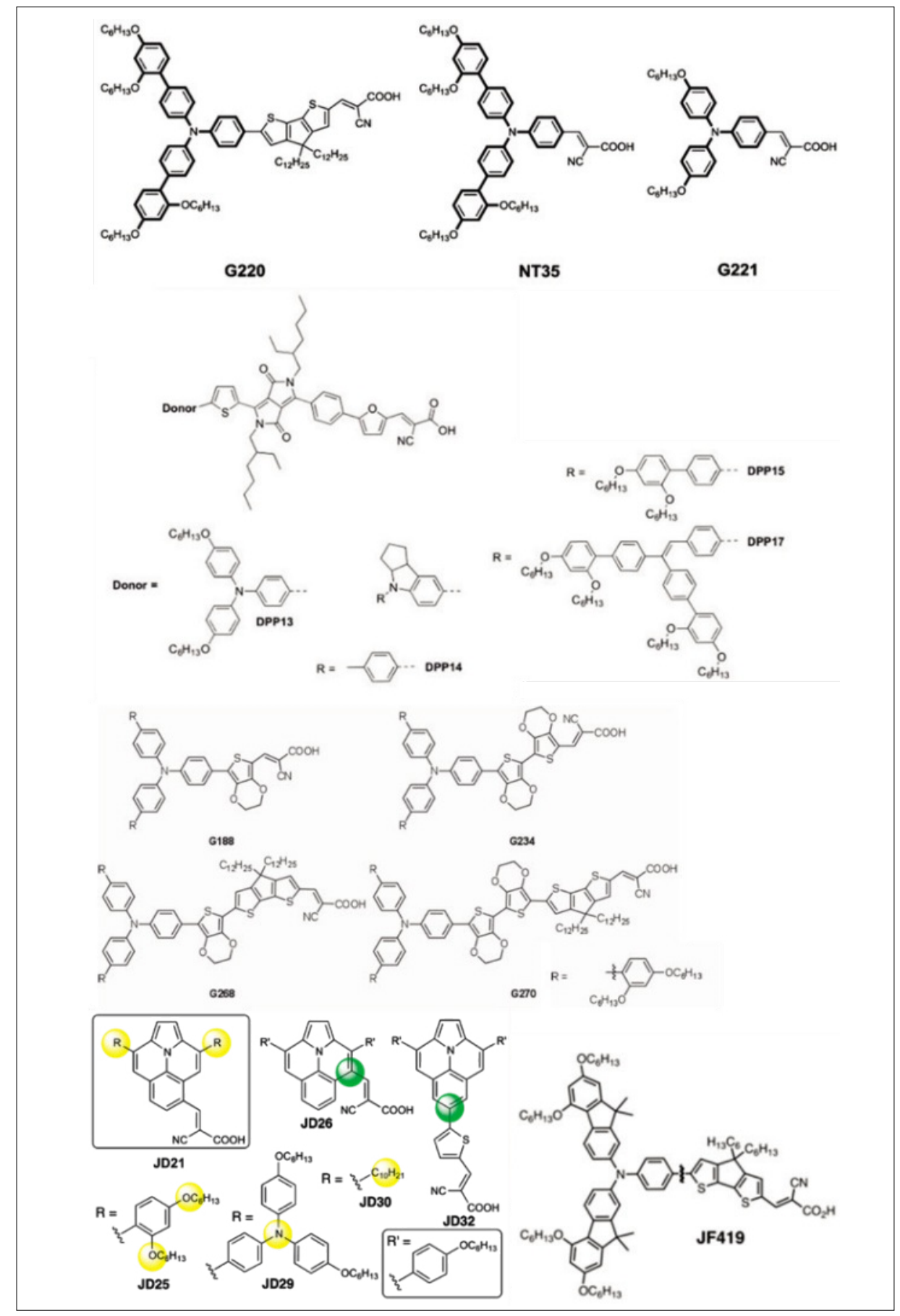

Fig.6. Representative metal-free organic sensitizers. the absorptivity of the complex, compared to an unsubstituted 2,2'-bipyridine ligand, and 2,2'-bipyridine-4,4'-dicarboxylic acid serves as an electron-accepting and anchoring ligand to the $\mathrm{TiO}_{2}$. The short-circuit current density $\left(J_{\mathrm{SC}}\right)$, open-circuit voltage $\left(V_{\mathrm{OC}}\right)$ obtained for $\mathbf{L P 1}\left(8.3 \mathrm{~mA} \mathrm{~cm} \mathrm{~cm}^{-2}\right.$ and $714 \mathrm{mV}$, respectively) suggest a power conversion efficiency of $4.7 \%$. Owing to the rational design of LP2, $J_{\mathrm{SC}}$ and $V_{\mathrm{OC}}$ increase to $13.2 \mathrm{~mA} \mathrm{~cm}^{-2}$ and $837 \mathrm{mV}$, respectively and give efficiencies of $8.6 \%$ in combination with a cobalt electrolyte. It is worth noting that this result closely matches that obtained with iodine/iodide redox couple $(8.7 \%)$, which has not been reported for a $\mathrm{Ru}(\mathrm{II})$ sensitizer yet. (Fig. 4)

Berlinguette and his colleagues have found that heteroatom substitution in the aliphatic chains can have a dramatic influence on dye regeneration in the context of organic dyes on the triphenyamine (TPA) unit, increasing the dye regeneration rate of up to three times with a cobalt electrolyte. [3] Since the TPA unit is directly donating into the organic dye systems, it was of interest to see if the same principle could be applied to metal-centered dyes. In this regard, Yin et al. synthesized a series of sulfur-atom containing ligands for $\mathrm{Ru}$ (II) sensitizers (CJ1, CJ2, CJ3) aiming to gain a greater understanding of the dye regeneration process and further improve the compatibility of ruthenium dyes with cobalt electrolyte systems. ${ }^{[4]}$

Motivated by the high efficiencies achievable with black dye (N749), different cyclometalated ruthenium(II) dyes with tridentate ligands are introduced. It is known that monodentate isothiocyanate ligands in black dye can uncoordinate easily, therefore tridentate cyclometalating ligands are used instead as the donating ligands to attain absorption spectrum close to that of black dye. SA-53 and SA-63 as representative dyes were synthesized by Aghazada and are illustrated in Fig. 3. In both dyes, alkoxy-substituted derivatives of triarylamine were incorporated on to the cyclometalating ligands to ensure hole extraction.

\subsection{Metal-free Organic Sensitizers}

Despite the fact that ruthenium-based complexes worked well and have been the most popular sensitizers over the past two decades, metal-free organic dyes became strong competitors as sensitizers in DSSCs due to their high molar extinction coefficient (50,000-200,000 $\mathrm{M}^{-1} \mathrm{~cm}^{-1}$ ), low cost, and high design flexibility of the molecules. Although organic sensitizers typically have narrower spectral bandwidths $(\Delta \lambda \approx 100-250 \mathrm{~nm})$, great efforts have been made in designing and synthesizing panchromatic organic sensitizers over the past few years. ${ }^{[5]}$ 


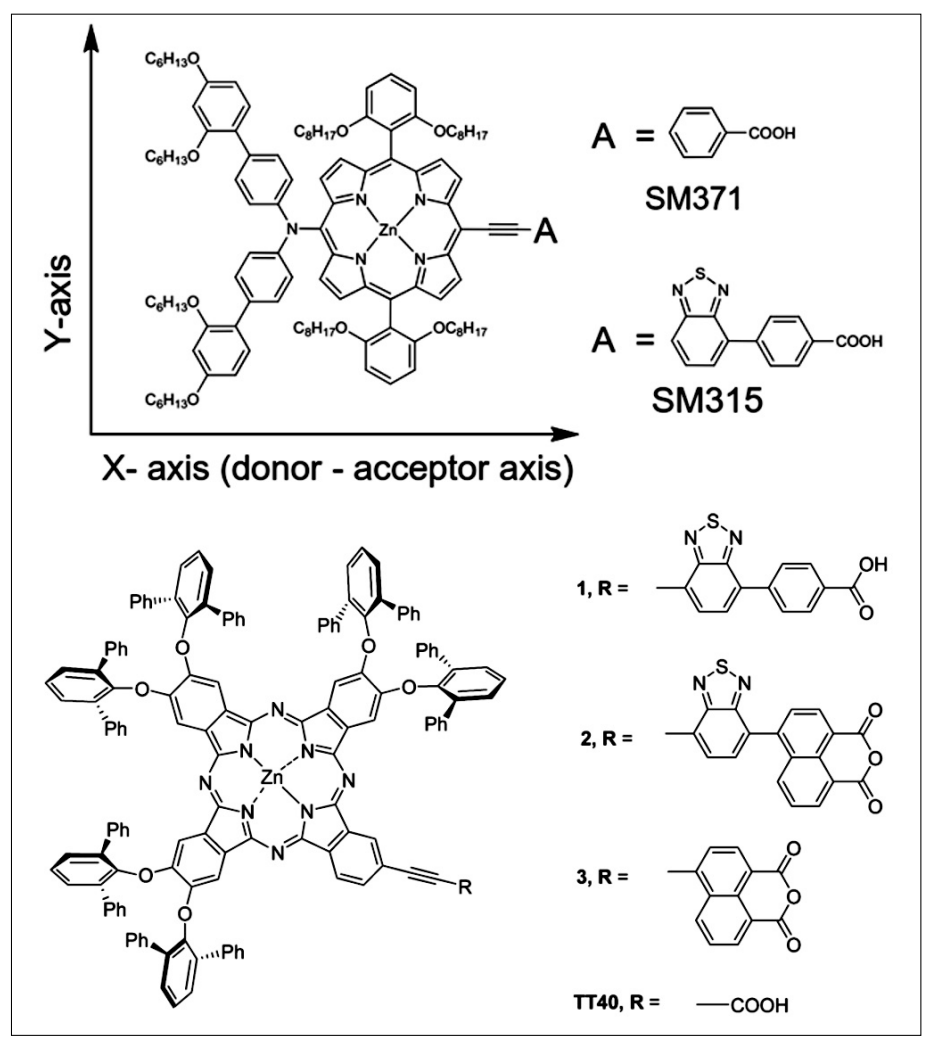

Fig. 7. Structures of porphyrin and phthalocyanine sensitizers. The structures have been coded SM371, SM315, ZnPc 1, 2, 3 , and TT40.

Donor- $\pi$ spacer-acceptor $(\mathrm{D}-\pi-\mathrm{A})$ architecture, in which electron-rich (donor) and electron-poor (acceptor) moieties are connected through a conjugated $(\pi)$ bridge, represents the most commonly adopted molecular structure for organic dyes. The acidic anchoring group is normally attached to the acceptor part as shown in Fig. 5 or donor parts for p-type DSSCs to couple the molecule to the oxide surface. Photoexcitation induces an electron transfer from the donor to the acceptor moiety, so that the electron wavefunction couples to the titania conduction band states, while the hole wavefunction resides mainly away from the oxide surface to facilitate the interaction with the redox couple. Alkyl chains are normally attached to the periphery of the sensitizer to create a shield between holes in the redox couple and electrons in the titania, hence inhibiting recombination. ${ }^{[6]}$

Bearing the BPTPA donor, organic D- $\pi$-A dyes NT35 and G220, were synthesized and compared with $\mathbf{G 2 2 1}$ by Gao et al. ${ }^{[7]}$ (Fig. 6). The DSSC devices based on NT35 and G220 showed higher $J_{\mathrm{SC}}, V_{\mathrm{OC}}$ and better visible light spectra response in combination with the cobalt-based electrolyte than with an iodide-based electrolyte. The electron lifetime data indicates that the BPTPA donor has the ability to suppress electron recombination between $\mathrm{TiO}_{2}$ anode and redox couple. Therefore, the G220-based device shows the best PCE of $9.06 \%$. Frey et al. synthesized a new sensitizer (JF419) using a fluorene moiety to modify the BPTPA donor ${ }^{[8]}$ (Fig. 6). Due to meticulous design, the DSSCs based on JF419 give PCE up to $11.1 \%$ at half sun, and $10.3 \%$ overall efficiency at AM $1.5 \mathrm{G}$ simulated full sunlight in the presence of cobalt redox species.

We have designed and synthesized a series of high-performance blue-colored DPP-derived sensitizers, which widened the color palette of this promising, decoratively pleasing solar cell technology. ${ }^{[9]}$ We tried to increase the near infra-red (NIR) light response of asymmetric DPP dyes by further engineering the conjugated $\pi$-bridge and modulating the donating moieties (Fig. 6). These sensitizers provided good compatibility with cobalt electrolyte and the highest PCE for DPPbased sensitizers, to date. When used in combination with the cobalt redox system, high power conversion efficiencies up to 8-10\% were achieved, in particular more than $9 \%$ for DPP15 and higher than $10 \%$ for DPP17. Moreover, all dyes showed an attractive blue color in both solution and thin film state.

Gao et al. evaluated a range of organic sensitizers with the elongation of the $\pi$-bridges $(\mathbf{G 1 8 8}, \mathbf{G 2 3 4}, \mathbf{G 2 6 8}, \mathbf{G 2 7 0})^{[10]}$ (Fig. 6). The series of sensitizers showed slowly red-shifted electronic UV-vis spectra and a continuous decrease in oxidation potential, with which however, the photo-to-current response spectrum measurements did not agree for the corresponding devices. The compromised effect out of the elongation of the conjugated bridge yields the highest overall PCE of 9.24\% for $\mathbf{G 2 6 8}$ with the second longest $\pi$-bridge. It is be- lieved that a study of structure-property tuning will help the understanding about better molecular design and synthesis of highly efficient organic sensitizers.

We have developed a facile synthesis of Ullazine from simple commercial starting materials. ${ }^{[11]}$ The Ullazine core possesses a number of activated sites for the molecular engineering of Ullazine-based derivatives (Fig. 6). A DSSC device sensitized with Ullazine-based dye JD21 exhibited broad visible light spectra response giving rise to a PEC of $8.4 \%$. Due to the easy, scalable synthetic route and high performance in devices, we expect the Ullazine-unit to find broad applications in organic electronics with potential industry interests for the high-efficiency DSSCs.

\subsection{Porphyrin and Phthalocyanine Sensitizers}

Enlightened by the essential role that porphyrin derivatives play in photosynthesis of plants, we and others have tested numerous derivatives of porphyrin as sensitizers for DSSCs. ${ }^{[12]}$ It is worth noting that in these sensitizers, the porphyrin chromophore constitutes the $\pi$-bridge of the D- $\pi$-A structure by itself. Mathew et $a l$. meticulously designed the D- $\pi$-A porphyrins to synchronously increase cobaltelectrolyte compatibility and enhanced light harvesting properties in these sensitizers. ${ }^{[13]}$ Modification of the porphyrin chromophore with the bulky BPTPA donor and a 4-ethynylbenzoic acid gave the green-colored SM371 sensitizer, which exhibited a PCE of $12 \% .{ }^{[14]}$ Coupling of the proquinoidal BTD unit into SM371 afforded the panchromatic absorbing SM315 sensitizer (Fig. 7). SM315 demonstrated an enhancement in the absorption of the valley region inducing an increased $J_{\mathrm{SC}}$ of 18.1 as compared to $15.9 \mathrm{~mA} \mathrm{~cm}-2$ for SM371. Despite a slightly decreased $V_{\text {OC }}$ down to $0.91 \mathrm{~V}$, the much increased $J_{\mathrm{SC}}$ of SM315 results in an overall PCE of $13.0 \%$, outperforming SM371 (Fig. 8). Therefore, sensible molecular engineering of meso-substituted porphyrins allowed chemists to realize high-performance sensitizers, SM371 and SM315, that exhibit unprecedented photon-to-current conversion efficiencies under standard AM 1.5 G illumination.

Phthalocyanines (Pcs) are structural analogues of porphyrins with similar broad light-harvesting abilities in the long wavelength red and NIR spectral regions. ${ }^{[15,16]}$ In view of the fact that porphyrins always suffer from low photo-stability and low molecular absorption coefficients in the NIR region where, however, the flux of solar photons is at a maximum, the Pcs have the ability to compensate this disadvantage due to their extremely high absorbance in the NIR region of the electromagnetic 


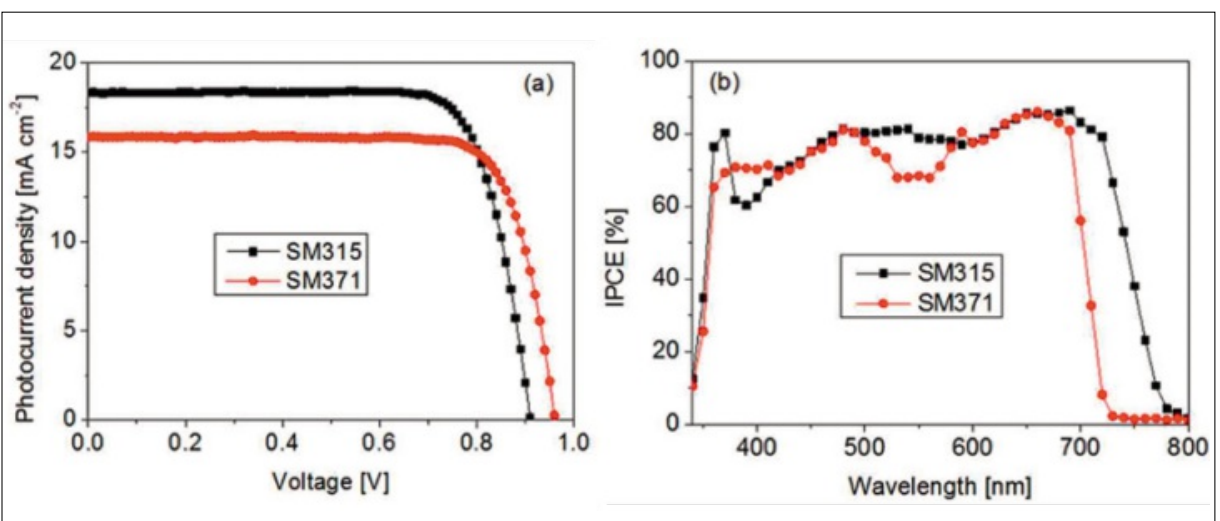

Fig. 8. Comparison of (a) J-V curves under AM1.5 G illumination ( $\left.100 \mathrm{~mW} \mathrm{~cm}{ }^{-2}\right)$ and (b) photocurrent response spectra of SM371 (red) and SM315 (black).

spectrum. In addition, Pcs have reasonable thermal and chemical stability and present appropriate energy offsets when used as sensitizers for $\mathrm{TiO}_{2}$ films, thus presenting themselves as perfect light-harvesting molecules for light-to-electricity conversion devices. Ince et al. synthesized a number of novel NIR-absorbing zinc-based phthalocyanines with a donorchromophore-acceptor/anchoring group regime to investigate their performance in solar cell devices. In order to extend the absorption spectra, benzodithiadiazole was used as an electron acceptor moiety. 2,6-Diphenylphenoxy bulky groups were attached to maintain the minimization of aggregation and the carboxylic acid or the anhydride unit was adopted as an anchoring group. ${ }^{[17]}$ These dyes are utilized as sensitizers in dye-sensitized solar cells and compared with that of reported Pc sensitizer TT40, which has an ethynyl bridge between the anchoring carboxy group and the Pc chromophore. The new ZnPcs showed red-shifted absorption maximum of $c a .10$ $\mathrm{nm}$ compared to that of TT40. However, although the red-shifted spectral response is promising, these cells gave only modest PCE of $c a$. 3\%, due to the lower LUMO level of the new Pcs, hindering efficient electron injection from the excited sensitizer to the $\mathrm{TiO}_{2}$.

\section{Organometal Trihalide Perovskites}

During the past 20 years, oxide perovskites, alkali metal halide perovskites and organometal halide perovskites $\left(\mathrm{AMX}_{3}\right)$ have been extensively studied. These perovskites consist of a wide range of organic cations (A: aliphatic or aromatic ammonium) and divalent metal cations $\left(\mathrm{M}: \mathrm{Cu}^{2+}, \mathrm{Ni}^{2+}, \mathrm{Co}^{2+}, \mathrm{Fe}^{2+}, \mathrm{Mn}^{2+}, \mathrm{Pd}^{2+}, \mathrm{Cd}^{2+}\right.$, $\mathrm{Ge}^{2+}, \mathrm{Sn}^{2+}, \mathrm{Pb}^{2+}, \mathrm{Eu}^{2+}$, etc.) (Fig. 9). Among these combinations, perovskites containing methylammonium (MA) or formamidinium (FA) as the A cation and metals from the fourth main group (4A, including $\left.\mathrm{Ge}^{2+}, \mathrm{Sn}^{2+}, \mathrm{Pb}^{2+}\right)$ as the $\mathrm{M}$ cation raised interest due to their excellent optoelectronic properties and potential for low-temperature solution processable films. ${ }^{[18]}$ For example, the methyl ammonium lead iodide $\left(\mathrm{CH}_{3} \mathrm{NH}_{3} \mathrm{PbI}_{3}\right)$ perovskite material has a panchromatic absorption (down to $c a .800$ $\mathrm{nm})$, direct band gap $(1.55 \mathrm{eV})$, a large absorption coefficient $\left(1.5 \times 10^{4} \mathrm{~cm}^{-1}\right.$ at 550 $\mathrm{nm}),{ }^{[19]}$ low exciton binding energy $(<25$ $\mathrm{meV}$ in $\left.\mathrm{MAPbI}_{3}\right),{ }^{[20]}$ very high charge carrier mobility $\left(66 \mathrm{~cm}^{2} / \mathrm{Vs} \text { for } \mathrm{MAPbI}_{3}\right)^{,[21]}$ ambipolar charge transport,[22] large electron and hole diffusion lengths $(175 \mu \mathrm{m})^{[23]}$ and low non-radiative recombination rates.[24]

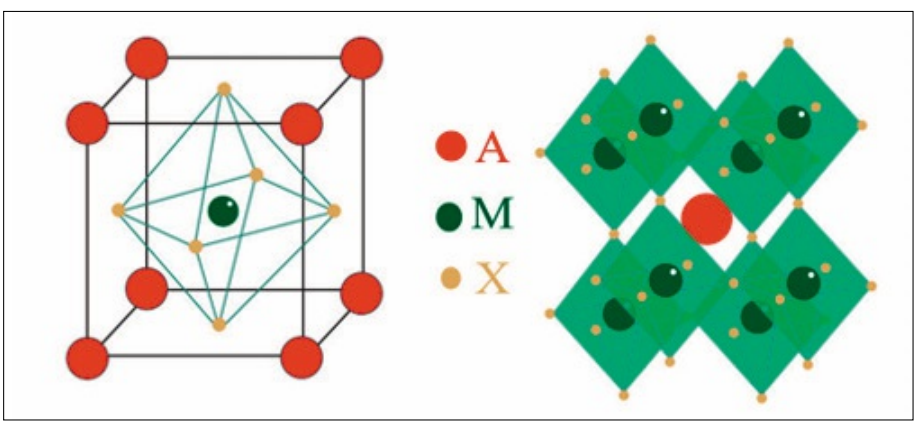

Fig. 9. Basic perovskite structure is shown as ball and stick model and their extended network structure consisting of corner-shared octahedra.

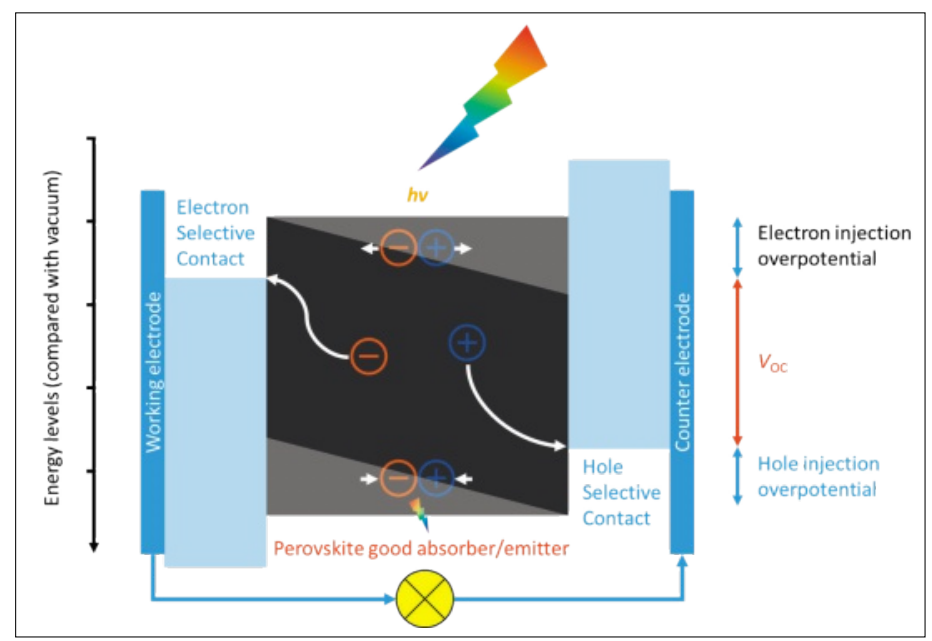

Fig. 10. One typical schematic working mechanism of a perovskite solar cell. 

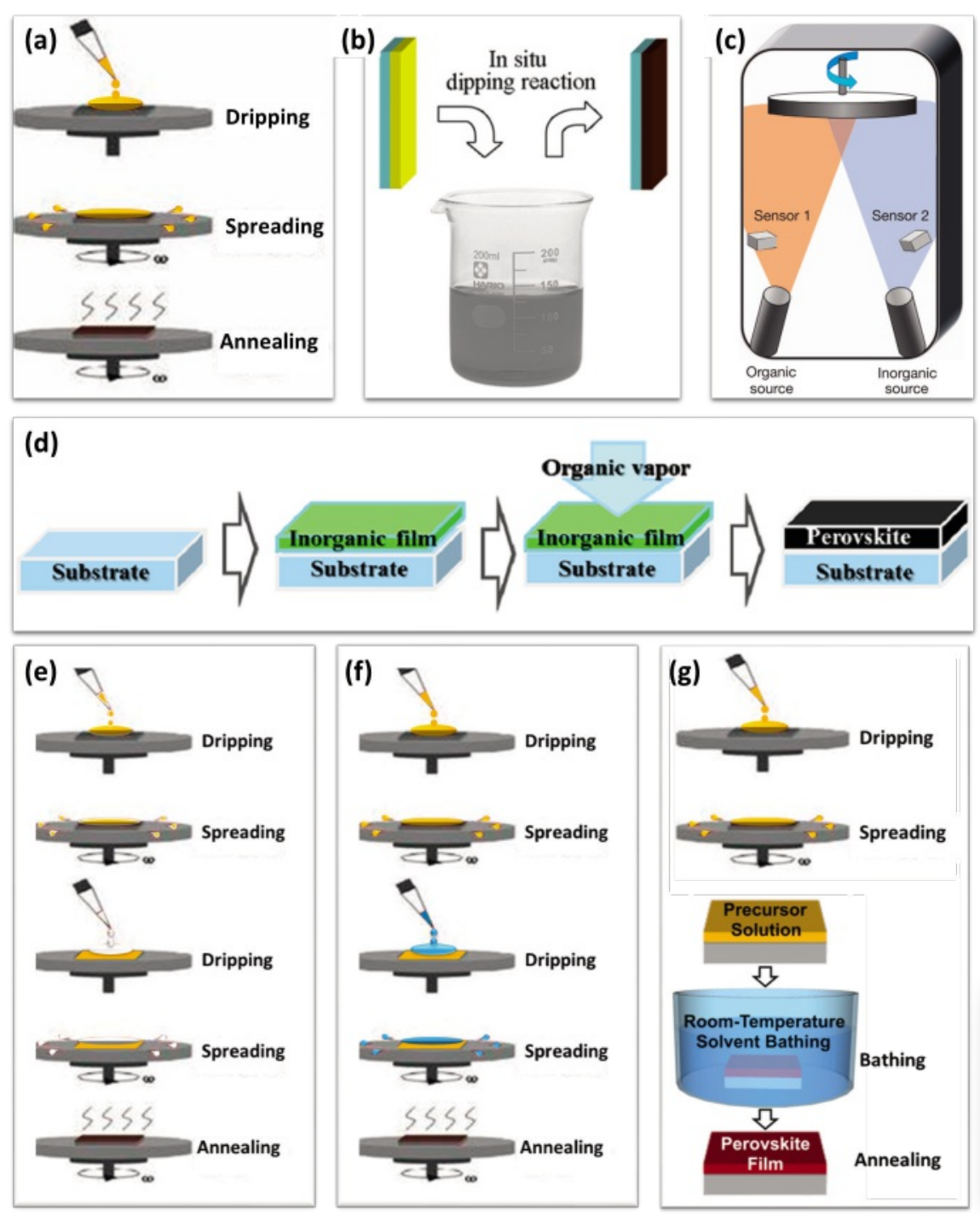

(h)
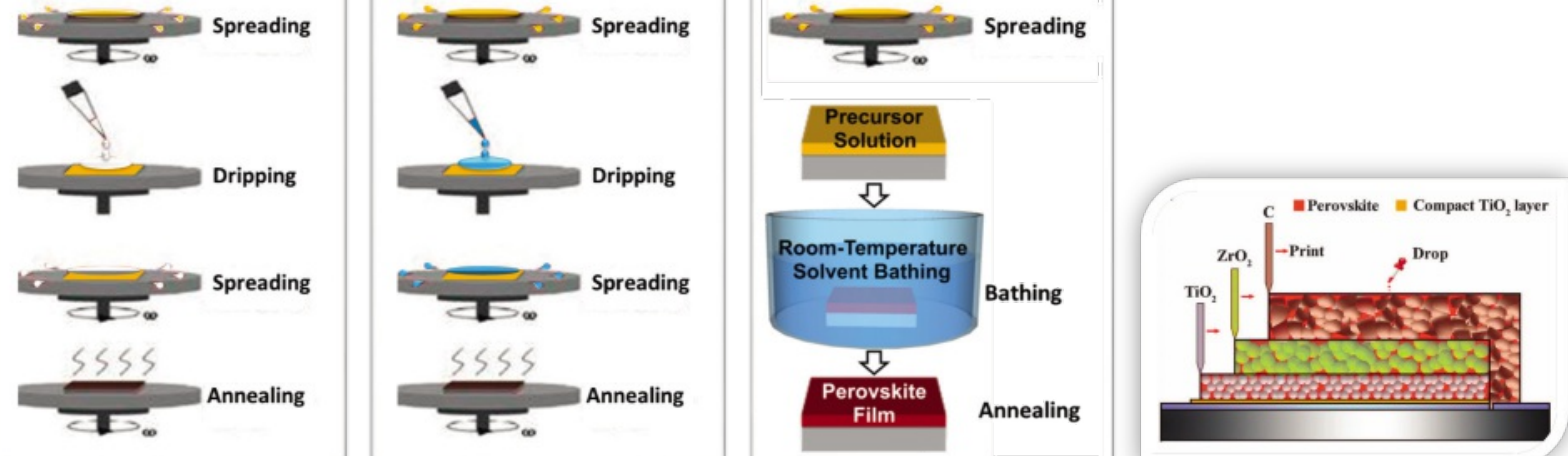

Fig. 11. Methods to prepare perovskite active layers. (a) One-Step Precursor Deposition (OSPD); (b) Sequential Deposition Method (SDM); (c) Dual-Source Vapor Deposition (DSVD); (d) Vapor-Assisted Solution Process (VASP); (e) Two step Spin-coating;. (f) Anti-solvent Treatment; (g) Solvent-solvent extraction (SSE); (h) Drop-casting.

The sequential deposition method was first developed by Mitzi et al. for the fabrication of perovskite film. ${ }^{[26]}$ Burschka et al. used this method to fabricate a solar cell where the $\mathrm{PbI}_{2}$ is spin-coated onto the nanoporous titania film and subsequently transformed into the perovskite by exposing it to a solution of $\mathrm{CH}_{3} \mathrm{NH}_{3} \mathrm{I}^{\left[{ }^{[28]} \text { The }\right.}$ perovskite film is formed instantaneously within the nanoporous host upon contacting the two components. The sequential deposition method allows flexible control over the perovskite crystallization procession compared to the traditional one-step deposition method. Employing this technique, the reproducibility of the solid-state mesoscopic solar cells' performance is greatly improved and a new record power conversion efficiency (PCE) of $15 \%$ is measured under standard AM1.5G test conditions (Fig. 12). This improvement in the power conversion efficiency compared to the dye-sensitized solar cells created new opportunities for the low cost room temperature fabrication of perovskite-based thin-film devices.

Pellet et al. demonstrated a mixed cation perovskite $(\mathrm{MA})_{\mathrm{x}}(\mathrm{FA})_{1-\mathrm{x}} \mathrm{PbI}_{3}(\mathrm{x}=0$ to 1) sensitized photovoltaic device. ${ }^{[35]}$ The formamidinium cation is used to replace methylammonium in lead iodide perovskites, trying to take advantage of the red-shifted absorption onset of $\mathrm{FAPbI}_{3}$ compared to that of $\mathrm{MAPbI}_{3}$. The mixed cation perovskite $\mathrm{MA}_{0.6} \mathrm{FA}_{0.4} \mathrm{PbI}_{3}$ exhibits superior PV performance to the single cation analogues owing to a higher short circuit photocurrent without compromising the photovoltage. Using this new perovskite, it is possible to fabricate devices showing $14.9 \%$ PCE under the AM1.5G simulated

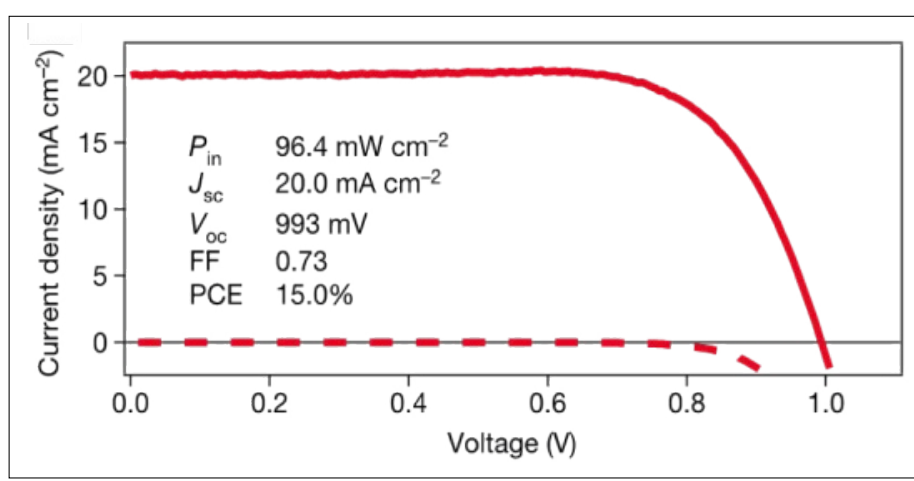

Fig. 12. J-V curves for a best-performing cell made of sequential deposition method measured at a simulated AM 1.5G solar irradiation of $96.4 \mathrm{~mW} \mathrm{~cm}^{-2}$ (solid line) and in the dark (dashed line). 
solar spectrum (Fig. 13a). The strategy of mixing organic cations represents a new concept to further improve photovoltaic efficiency of perovskite solar cells.

Malinkiewicz et al. fabricated a p-i-n thin film solar cell using sublimated $\mathrm{CH}_{3} \mathrm{NH}_{3} \mathrm{PbI}_{3}$ perovskite layer as light absorber and two very thin electron- and hole-blocking layers of organic molecules. [36] The uniform $\mathrm{CH}_{3} \mathrm{NH}_{3} \mathrm{PbI}_{3}$ perovskite thin film was prepared by dual-source evaporation of the two precursors $\mathrm{CH}_{3} \mathrm{NH}_{3} \mathrm{I}$ and $\mathrm{PbI}_{2}$. The current-voltage $(\mathrm{J}-\mathrm{V})$ characteristics of a typical small area $\left(0.09 \mathrm{~cm}^{2}\right)$ perovskite solar cell measured in the dark and under light intensities of 100,50 and $10 \mathrm{~mW} \mathrm{~cm}^{-2}$ are shown in Fig. $13 \mathrm{~b}$. The short-circuit current density $\left(J_{\mathrm{SC}}\right)$, open-circuit voltage $\left(V_{\mathrm{OC}}\right)$ and fill factor $(F F)$, are respectively $16.12 \mathrm{~mA} \mathrm{~cm}^{-2}, 1.05$

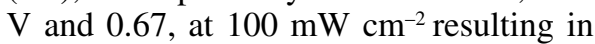
a power conversion efficiency of $12.04 \%$. The high $V_{\mathrm{OC}}$ indicates that there are scanty surface and sub-band-gap states in the perovskite film. The device performance under full sun is remarkable in view of the very thin perovskite film of only $285 \mathrm{~nm}$.

Besides these record efficiencies, our group also studied fundamental aspects of the perovskite material and the impact on the devices. For example, Dualeh et al. studied the effect of annealing temperature on film morphology of perovskite solar cells, ${ }^{[37]}$ impedance spectroscopic analysis of perovskite solar cells ${ }^{[38]}$ and thermal behavior of methylammonium lead-trihalide perovskite;[39] Qin et al. used yttrium-doped nanocrystalline $\mathrm{TiO}_{2}$ photoanodes for perovskite solar cells; ${ }^{[40]}$ Dar et al. investigated the role of chloride in organic-inorganic halide perovskites. ${ }^{[41]}$ Finally, Lioz et al. fabricated hybrid lead iodide perovskite and lead sulfide QD heterojunction solar cell to obtain a panchromatic response. ${ }^{[42]}$

\subsection{New Hole-transporting Materials for Perovskite Solar Cells}

Selective contacts as an electron acceptor (hole blocking) and hole transporting (electron blocking) layers are paramount in perovskite solar cells for efficient charge separation and extraction (Fig. 14). The most commonly used selective contact materials for electrons and holes in a typical PSC are compact $\mathrm{TiO}_{2}$ and spiroOMeTAD, respectively. Finding another stable and cost-effective selective hole contact is one of the main branch topics of PSCs. A variety of hole-transporting materials with tunable HOMO levels of small molecules ${ }^{[43-47]}$ and polymers ${ }^{[48-50]}$ and inorganic $\mathrm{CuI}^{[51]}$ and $\mathrm{CuSCN}$ have been applied, which exhibited similar performance to that of spiro-OMeTAD.
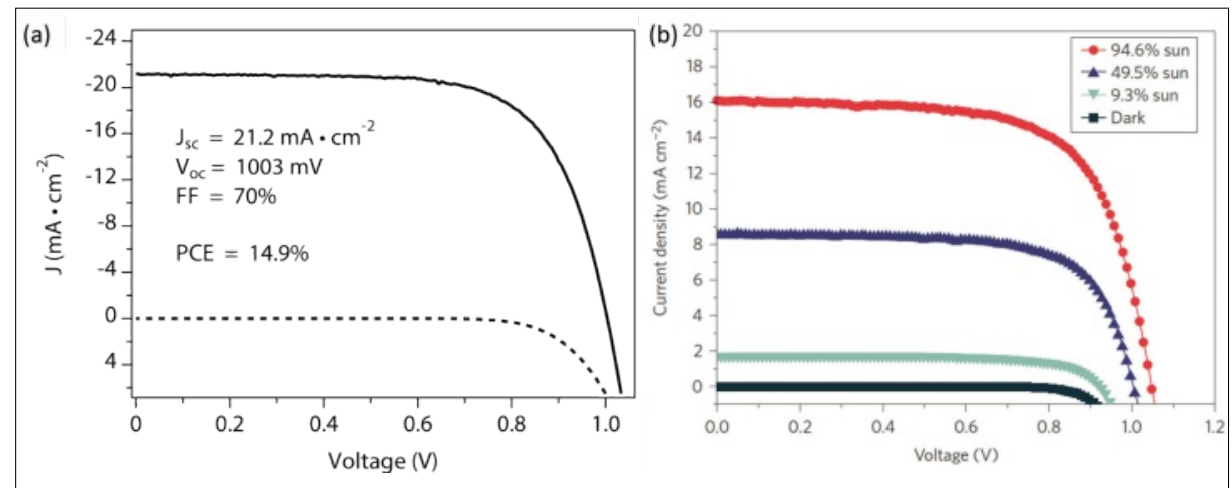

Fig. 13. (a) $\mathrm{J}-\mathrm{V}$ curves of the record cell based on $\left(\mathrm{CH}_{3} \mathrm{NH}_{3}\right)_{0.6}\left(\mathrm{HN}=\mathrm{CHNH}_{3}\right)_{0.4} \mathrm{Pbl}_{3}$ measured under a simulated AM1.5G solar spectrum at $98.2 \mathrm{~mW} \mathrm{~cm}^{-2}$ and in the dark. (b) Photocurrent density versus voltage at 100,50 and $10 \mathrm{~mW} \mathrm{~cm}^{-2}$ and in the dark of the cell from dual-source vapor deposition (DSVD).

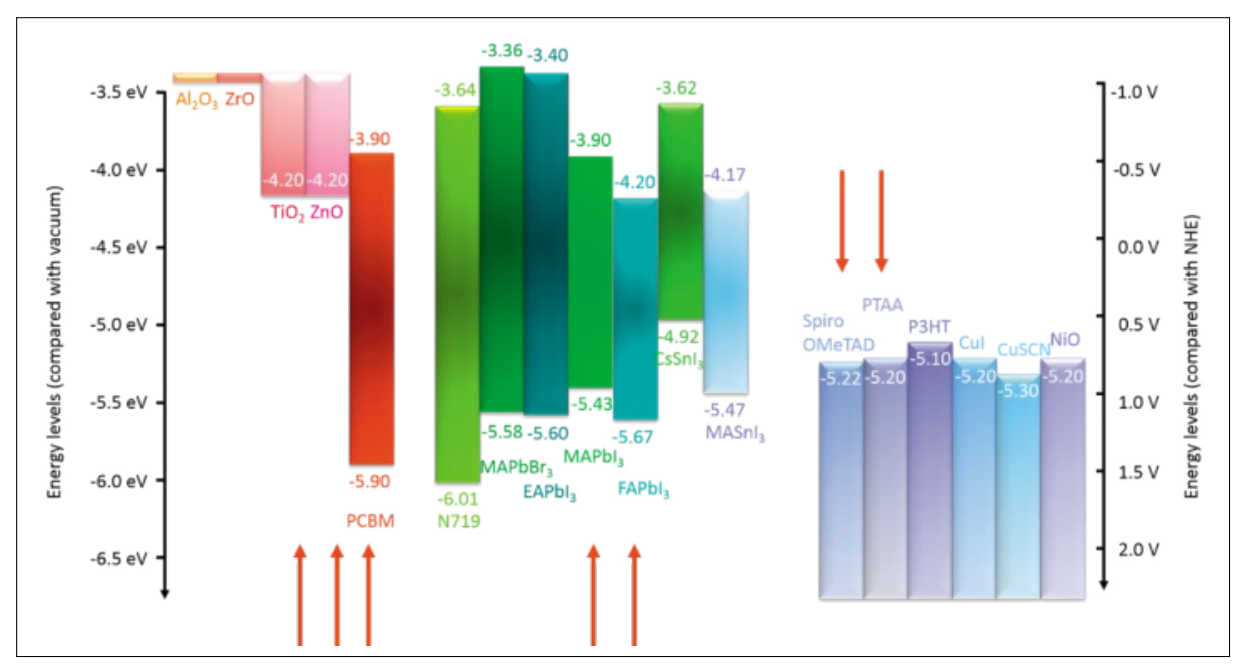

Fig. 14. Energy level alignment for different materials acting as the electron selective contact material (ETM) (left), absorbers (middle) and hole selective contact materials (HTMs) (right) in solar cells. (The red arrows indicate the most commonly used materials).

\subsubsection{Organic Hole-transporting Materials}

Qin et al. applied a variety of new organic hole-transporting materials to replace spiro-OMeTAD including starshaped conjugated molecules, ${ }^{[52]}$ oligotriphenylamine ${ }^{[53]}$ and fused A-D-A type oligoacenes $^{[54]}$ (Fig. 15). All these molecules have suitable highest occupied molecular orbitals (HOMO) and the lowest unoccupied molecular orbitals (LUMO), so that the holes can be either injected from the perovskite or extracted efficiently with minimum driving force (Fig. 16). Under optimized conditions, these new HTMs showed similar or even higher power conversion efficiency compared to that of state-of-the-art spiro-OMeTAD.

We synthesized a series of novel cost-effective spiro-type HTM molecules (coded PST1 to PST4) (Fig. 15) for perovskite solar cells (PSC) that work efficiently even without a cobalt dopant. Especially, an X-ray diffraction study of PST1 revealed a unique quasi-spiro molecular configuration and found multiple
$\mathrm{CH} / \pi$ and $\pi-\pi$ intermolecular contacts. The device based on PST1 exhibited a PCE of $13.44 \%$, and a comparable $12.74 \%$ PCE was achieved with its undoped form, which paves the way for developing new low cost hole-transporting materials and industrialization of perovskite solar cells.

Ramos et al. investigated a non-aggregated phthalocyanine TT80 (see Fig. 15) as HTM for perovskite solar cells. ${ }^{[55]}$ After optimizing the deposition solvent and the additives, a maximum power conversion efficiency of $6.7 \%$ is achieved for the best cell under AM1.5G standard conditions demonstrating that phthalocyanines are suitable for the application as HTM in perovskite solar cells. These findings provide a way to engineer new HTM systems based on these highly stable and hydrophobic molecules to enhance overall stability of the perovskite solar cells.

Most recently, Rakstys et al. and Paek et al. synthesized two different new HTM molecules for perovskite solar cells (KR145 and PEH-1) (Fig. 15). They showed very promising photo-to-current 


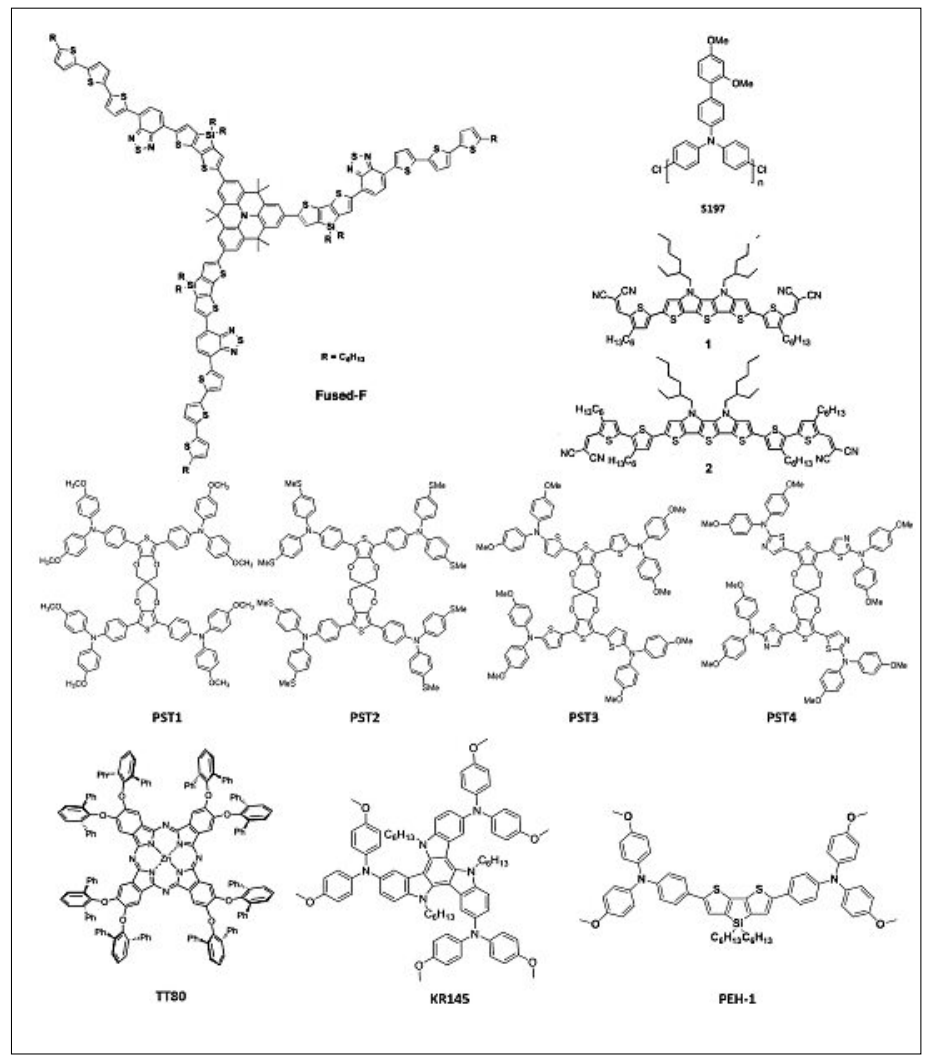

Fig. 15. Structures of synthesized and studied novel HTM molecules. conversion efficiencies and much higher stability compared with spiro-OMeTAD based devices.

\subsubsection{Inorganic Hole-transporting Materials}

Qin et al. explored the solutionprocessed inorganic p-type HTM, $\mathrm{CuSCN}$ in $\mathrm{CH}_{3} \mathrm{NH}_{3} \mathrm{PbI}_{3}$-based solar cells (Fig. 17). ${ }^{[56]}$ The use of CuSCN leads to an overall efficiency of $12.4 \%$ representing a $65 \%$ increase in $J_{\mathrm{SC}}$ and $9 \%$ in $V_{\mathrm{OC}}$ when compared with the device without HTM. The high $J_{\text {SC }}$ and IPCE values suggest efficient charge extraction and collection from the excited $\mathrm{CH}_{3} \mathrm{NH}_{3} \mathrm{PbI}_{3}$ to $\mathrm{TiO}_{2}$ and $\mathrm{CuSCN}$, respectively. This study provides the opportunity for integration of an abundant and inexpensive inorganic material for printable photovoltaics devices and green energy production.

\subsection{Perovskite Photo-detector}

Besides the applications in photovoltaics, organometal lead halide perovskites with a typical formula of $\mathrm{CH}_{3} \mathrm{NH}_{3} \mathrm{PbX}_{3}$ (where $\mathrm{X}$ is $\mathrm{Br}, \mathrm{Cl}$ or I) have also attracted significant attention as new optoelectronic materials for photodetectors, ${ }^{[57]}$ light emitting diodes ${ }^{[58]}$ and lasers. ${ }^{[24]}$

Domanski et al. developed a novel $\mathrm{CH}_{3} \mathrm{NH}_{3} \mathrm{PbI}_{3}$-based photodetector, which is operated at low voltage $(0.6 \mathrm{~V})$ and is characterized by a very high responsiveness in excess of $200 \mathrm{~A} \mathrm{~W}^{-1}$ (Fig. 18b). This translates to peak IPCE of $50,000 \%$ and an average gain of 1700 . The detector employs a geometry similar to the one pre-

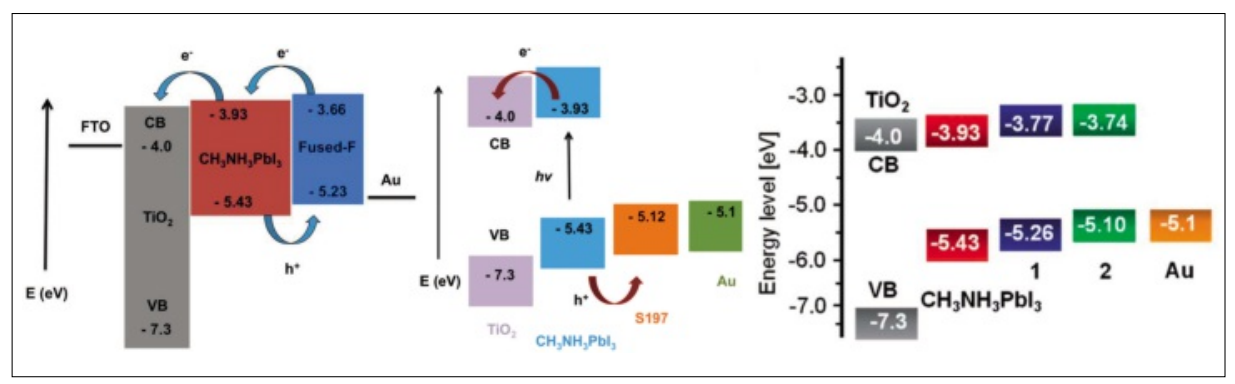

Fig. 16. Energy level diagram of respective HTM based perovskite solar cells indicating the energy level requirement for the new HTMs.

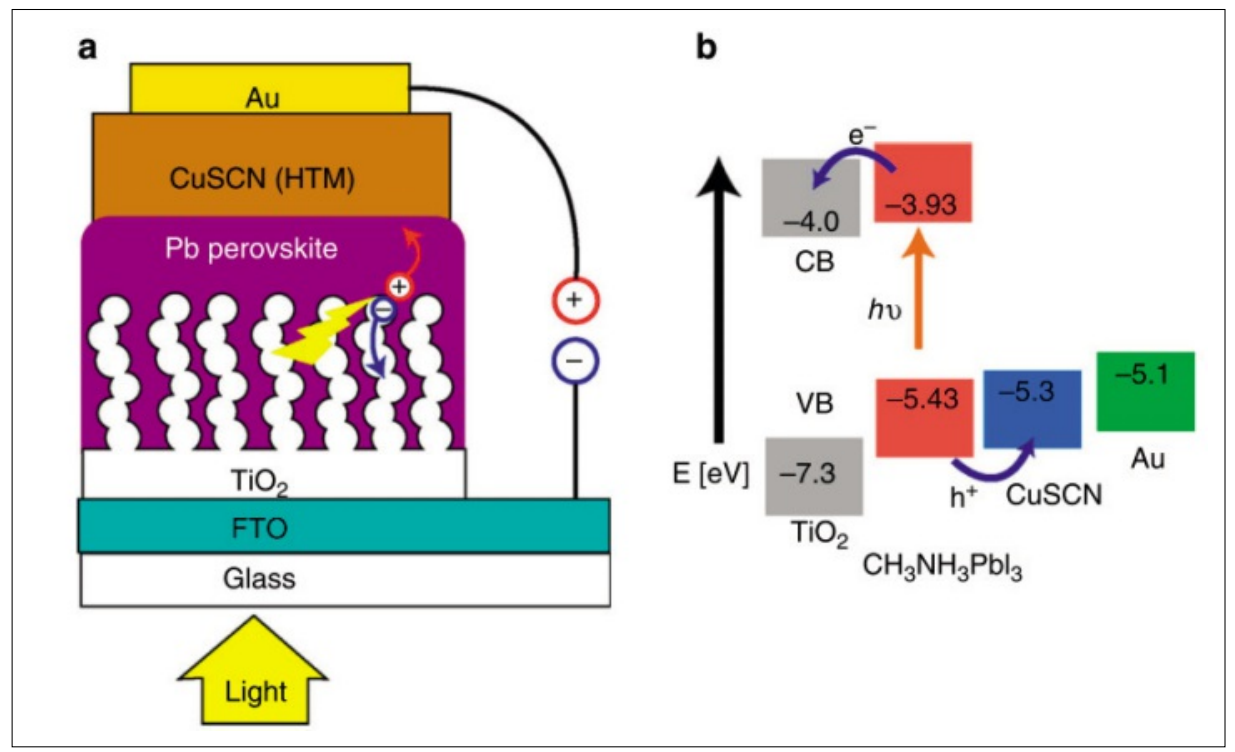

Fig. 17. Schematics device architecture and energy diagram. (a) Schematic drawing of crosssection of the perovskite solar cell: FTO glass, compact $\mathrm{TiO}_{2}$ underlayer, mesoporous $\mathrm{TiO}_{2}$ with infiltrated $\mathrm{CH}_{3} \mathrm{NH}_{3} \mathrm{Pbl}_{3}$, CuSCN HTM, and gold. (b) Energy level diagram of the device showing favorable electron injection and hole extraction. viously demonstrated by us for efficient solar cells (Fig. 18a). ${ }^{[59]}$ The detector exhibits high performance over a broad spectrum covering near UV and extending into the entire visible range while being IR-blind (IR is the main source of noise for Si photodetectors). Strong photocurrent amplification is observed when biasing the device in reverse bias (Fig. 18c). Although the device does not employ a blocking layer, it displays a decent photovoltaic efficiency of $11.1 \%$ when biased in the forward direction. Our results indicate that perovskite materials are promising candidates for low-cost, low-voltage and high-gain photodetectors operating across a broad visible spectrum. Due to their tuning ability of the bandgap by exchanging the A, B or $\mathrm{X}$ side of the $\mathrm{ABX}_{3}$ crystal this material opens the possibility to adjust the absorption edge further into the red or blue.

\section{Transition Metal Complexes for OLED}

The platinum group metal complexes have found application in organic light 


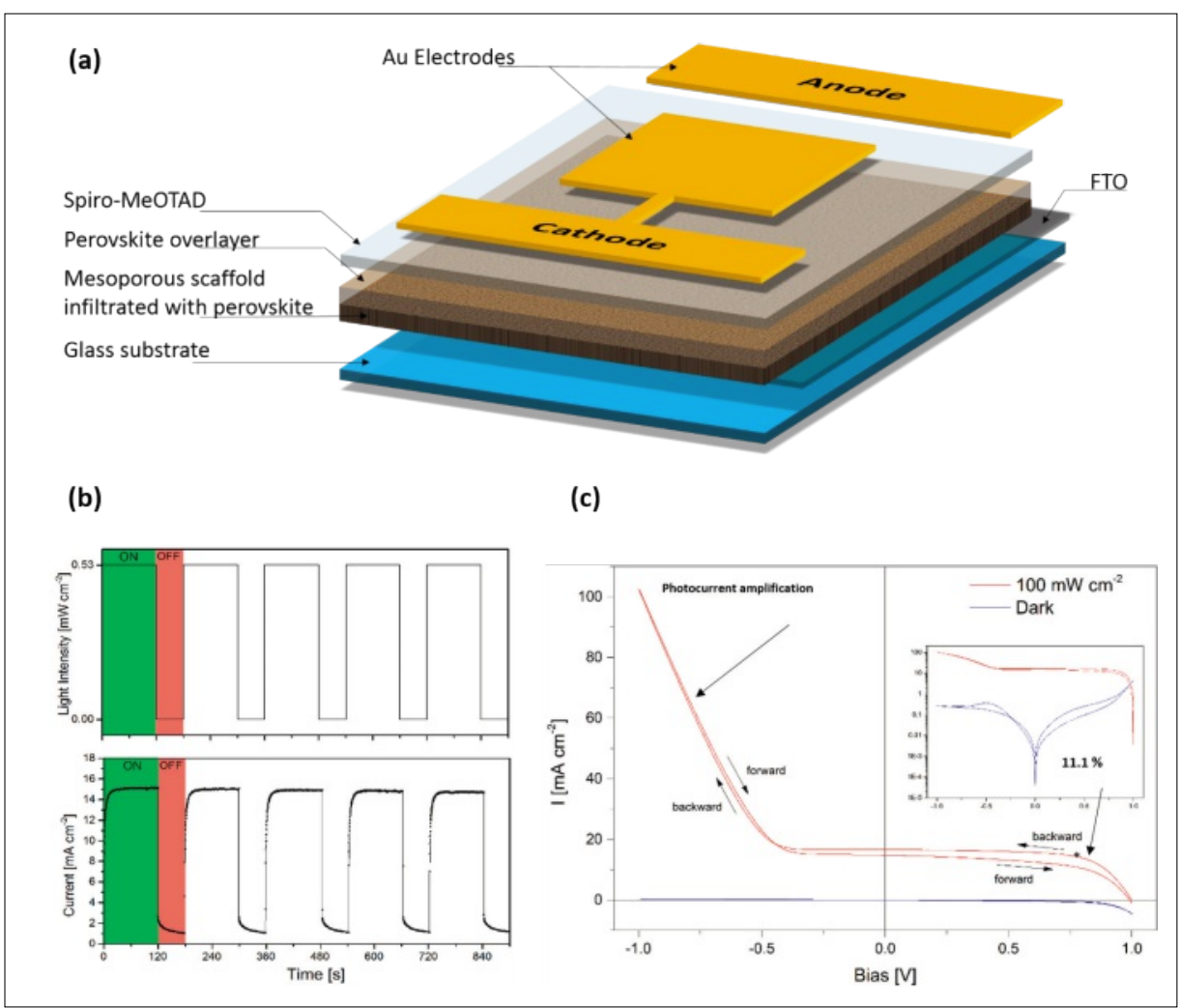

Fig. 18. (a) Architecture of the perovskite photodetector; (b) on-off response as the detector is illuminated with $0.53 \mathrm{~mW} \mathrm{~cm} \mathrm{~cm}^{-2} 550 \mathrm{~nm}$ light; (c) Current-voltage characteristics of the detector in dark and under $100 \mathrm{~mW} \mathrm{~cm}^{-2}$ white illumination.

emitting diodes (OLED) because of their enhanced singlet-to-triplet intersystem crossing resulting in almost quantitative phosphorescence quantum yields. In addition tuning the HOMO and the LUMO levels of the metal complexes can shift the color of these triplet emitters from blue to red. The high quantum yields are due to mixed-state emissions both from ligand-centered (LC) transitions and metal-to-ligand-charged-transfer (MLCT) transitions. [60] Choosing from the $5 \mathrm{~d}$ transition-metal series, transition metals like iridium, platinum, and osmium can achieve strong spin-orbit coupling and efficient mixed states of singlet MLCT and the ligand-based states, resulting in extremely high phosphorescence efficiencies.

Phosphorescent iridium complexes are one of the key components in organic light emitting diodes and light emitting electrochemical cells. There are a number of reasons for the choice of iridium metal complexes for OLED applications. The most useful property of these complexes is the low molar extinction coefficient in the visible regions, and formation of colorless complexes. In addition the octahedral complexes can be substituted with tailored ligands to tune photophysical and electrochemical properties. ${ }^{[61]}$ Therefore, a number of $\operatorname{Ir}(\mathrm{III})$ complexes with different types of ligands and/or ionic charges have been made by judicious molecular engineering. ${ }^{[62-74]}$ (Fig. 19). wavelength both in solution and as a thin film in devices higher than $600 \mathrm{~nm}$ without relying on extending the aromatic delocalization or interligand energy transfer. ${ }^{[65]}$ Although the photo-luminescence quantum yield of the iridium complexes is at the low end of red-emitting, $\mathbf{N 9 5 8}$ is a fairly good orange-red-emitting material giving rise to devices with excellent external quantum efficiencies (EQE) up to $10 \%$ (Fig. 20a).

To realize an iridium complex with degenerate emitting states of mixed character, we have developed $\mathbf{N 9 6 6}$ with very broad emission, which can be perceived as white light when tested upon photoexcitation and electro excitation. ${ }^{[66]}$ Although the device efficiency is pretty low, the preparation of a single molecular white light-emitting phosphorescent emitter is important because it demonstrates the potential of single organo-metallic complexes in the development of white LEDs (Fig. 20b).

\section{Metal Oxides or Alloys for $\mathrm{CO}_{2}$ Reduction and $\mathrm{H}_{2} \mathrm{O}$ Splitting}

It is always desirable to realize efficient electrochemical conversion of $\mathrm{H}_{2} \mathrm{O}$ and $\mathrm{CO}_{2}$ into fuel, which can be used as a means to store energy produced by variable renewable energy sources such as solar or wind. To realize large-scale deployment of this kind of system, the development of efficient electrocatalysts made of only

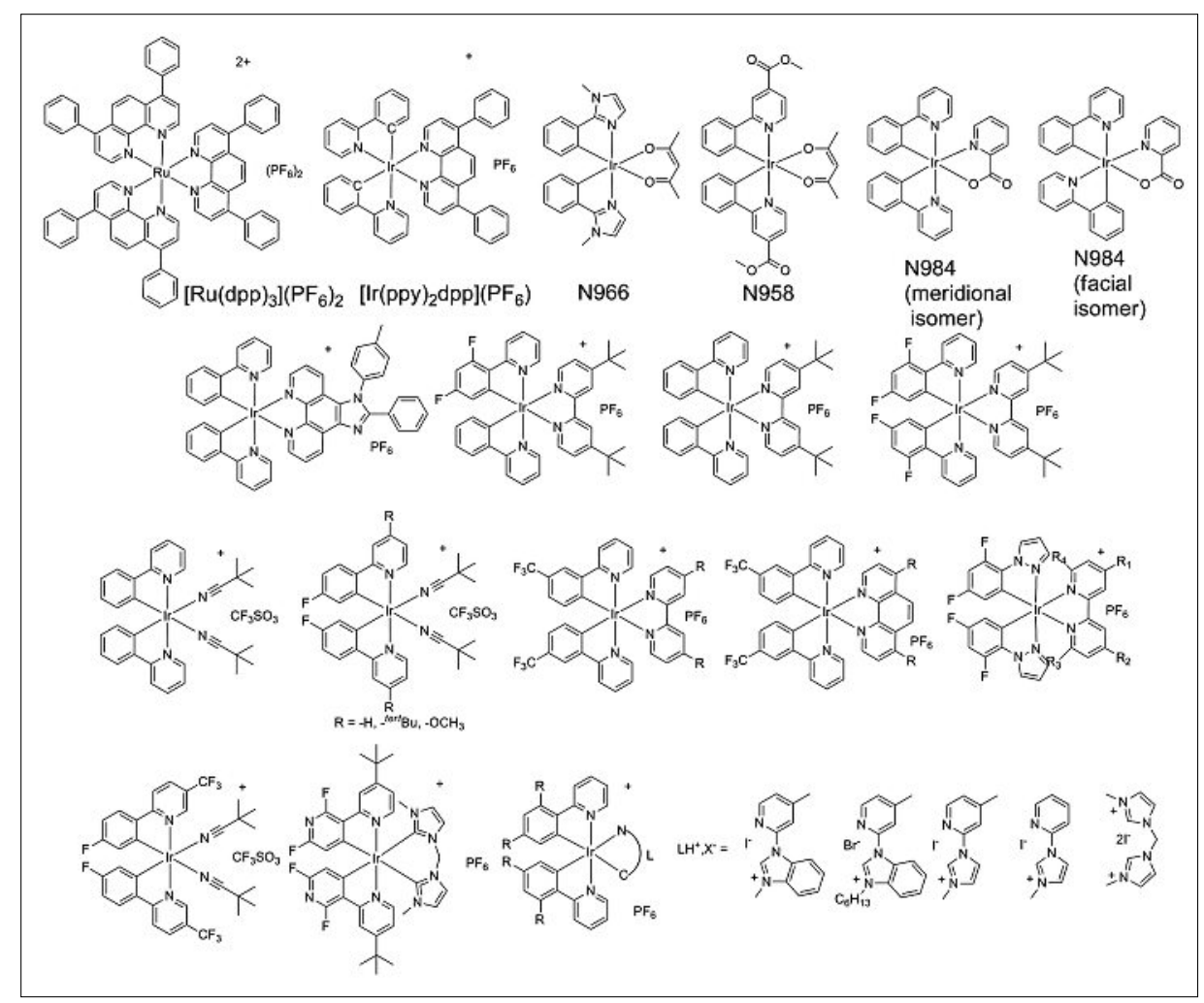

Fig. 19. Structures of synthesized and studied novel transition metal complexes for OLED. ${ }^{[62-74]}$ 


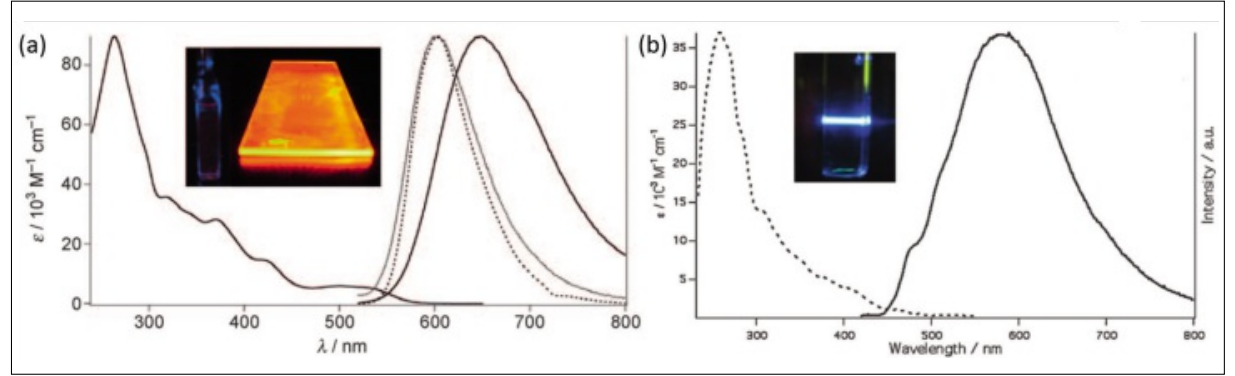

Fig. 20. (a) Absorption (solid line, left) and emission (solid line, right) spectra of $\mathbf{N} 958\left(10^{-5} \mathrm{M}\right)$ in acetonitrile. Dotted line: emission of PMMA: 0.7 wt\% $N 958$ film; dashed line: device emission. The insert shows a photo of the $\mathbf{N 9 5 8}$ solution and of the PMMA film excited at $365 \mathrm{~nm}$. (b) Absorption (left dotted line) and emission spectra (right full line) of $\mathbf{N 9 6 6}$ in dichloromethane. The inset shows the chemical structure of N966. The photo shows the white-light emission of N966 obtained upon excitation using $355 \mathrm{~nm}$ laser light.

earth-abundant elements is vital.[75-77] In particular, more effective catalysts for artificial photosynthesis and electrolysis of hydrogen or carbon-containing fuels are required due to the fact that the 4-electron oxygen evolution reaction (OER) is kinetically slow. ${ }^{[76]}$

Using a molecular catalyst, for the first time, Schreier et al. demonstrated an efficient reduction of $\mathrm{CO}_{2}$ to $\mathrm{CO}$ on a protected $\mathrm{Cu}_{2} \mathrm{O}$ photocathode ${ }^{[78]}$ (Fig. 21a). The device exhibited high photovoltages up to $560 \mathrm{mV}$ and a photocurrent density of 2.1 $\mathrm{mA} \mathrm{cm}$, which is the highest photocurrent ever observed for $\mathrm{CO}_{2}$ reduction on an oxide material. The stable and selective reduction of $\mathrm{CO}_{2}$ over several hours is realized through protection of the $\mathrm{Cu}_{2} \mathrm{O}$ photocathode by $\mathrm{ALD} \mathrm{TiO}$. It is observed that protic electrolyte additives should be used to overcome the unexpected charge transfer limits on the protected photo-cathode surface. Upon the observation of charge transfer, we speculate that the protic additive changes the catalytic pathway to ignore charged catalyst intermediates. We therefore expect these findings to be broadly appreciated in the photoelectrochemical community involving semiconductors and molecular catalysts.

Luo et al. showed a very efficient and cost-effective water-splitting cell using a high efficiency solution-processed per- ovskite solar cell and a dual-functional earth-abundant catalyst ${ }^{[79]}$ (Fig. 21b). $\mathrm{NiFe}$ layered double hydroxide is used as the catalyst electrode, which exhibits high activity toward both the oxygen and hydrogen evolution reactions in alkaline electrolyte. A solar-to-hydrogen conversion efficiency of $12.3 \%$ is achieved when the two elements are combined, which shows a water-splitting photocurrent density of around 10 milliamperes per square centimeter. Currently, it is the perovskite instability that is limiting the cell lifetime.

\section{Conclusion}

In this review, we have presented an overview of the dedicated research directions of the Group for Molecular Engineering of Functional Materials (GMF). This includes molecular engineering sensitizers constructed from ruthenium complexes, organic molecules, porphyrins and phthalocyanines. Manipulation of organometal trihalide perovskites, and charge transporting materials for high performance perovskites solar cells and photo-detectors were described. Controlling phosphorescence color, and quantum yields in iridium complexes by tailoring ligands for organic light emitting diodes are demonstrated. Efficient reduction of
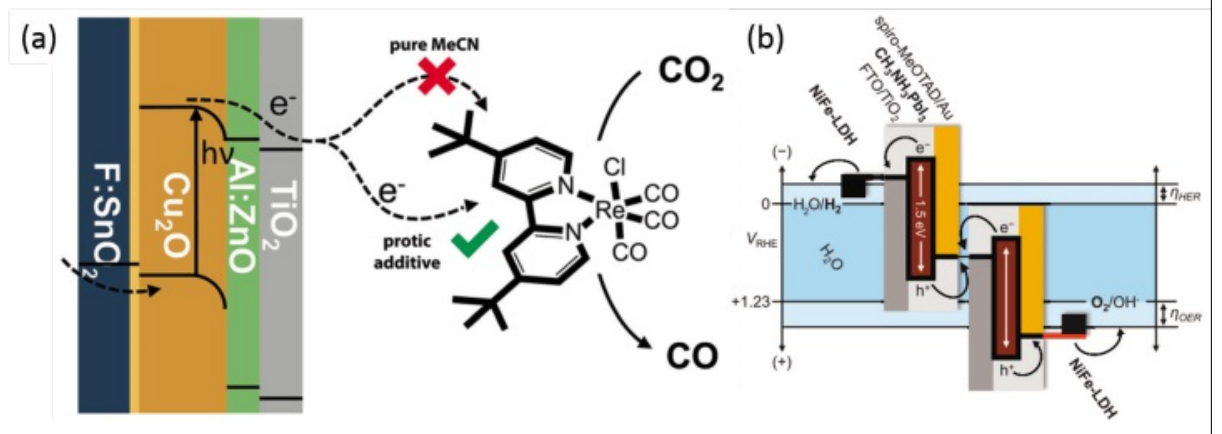

Fig. 21. (a) Schematic of the photoelectrochemical $\mathrm{CO}_{2}$ reduction process involving protected $\mathrm{Cu}_{2} \mathrm{O}$ photocathodes and a Re-based molecular catalyst. (b) A generalized energy schematic of the perovskite tandem cell for water splitting.

$\mathrm{CO}_{2}$ to $\mathrm{CO}$ using molecular catalysts on a protected $\mathrm{Cu}_{2} \mathrm{O}$ photocathode, and cost-effective water-splitting cell using a high efficiency perovskite solar cell are presented. With the dedicated students and post-docs, the group is optimistic to push the research frontiers and find solutions to the energy and environment.

\section{Acknowledgements}

We acknowledge financial support from FNS-NRP 70, CTI 15864.2 PFNM-NM, Solaronix, Aubonne, Switzerland, and from the European Union Seventh Framework Programme [FP7/2007-2013] under grant agreement $\mathrm{N}^{\circ} 604032$ of the MESO project, and (FP7/2007-2013) ENERGY.2012.10.2.1; NANOMATCELL, grant agreement no. 308997. We thank 'SEFRI' for funding the H2020-ICT-2014-1, Soledlight project, grant agreement $\mathrm{N}^{\circ}: 643791$.

Received: April 6, 2015

[1] P. Gao, M. Grätzel, M. K. Nazeeruddin, M. Gra, in 'Adv. Concepts Photovoltaics', Eds. J. N. Arthur, C. Gavin, C.B. Matthew, RSC, 2014, pp. 186-241.

[2] L. E. Polander, A. Yella, B. F. E. Curchod, N. Ashari Astani, J. Teuscher, R. Scopelliti, P. Gao, S. Mathew, J.-E. Moser, I. Tavernelli, U. Rothlisberger, M. Grätzel, M. K. Nazeeruddin, J. Frey, Angew. Chem. Int. Ed. 2013, 52, 8731.

[3] K. C. D. Robson, K. Hu, G. J. Meyer, C. P. Berlinguette, J. Am. Chem. Soc. 2013, 135, 1961.

[4] C.-J. M. Yin, 'Molecular Engineering of Sensitisers for Conversion of Solar Energy into Electricity', EPFL Master thesis, 2014.

[5] A. Mishra, M. K. R. Fischer, P. Bäuerle, Angew. Chem. Int. Ed. 2009, 48, 2474.

[6] Y.-S. Yen, H.-H. Chou, Y.-C. Chen, C.-Y. Hsu, J. T. Lin, J. Mater. Chem. 2012, 22, 8734.

[7] P. Gao, Y. J. Kim, J.-H. Yum, T. W. Holcombe, M. K. Nazeeruddin, M. Grätzel, J. Mater. Chem. A 2013, 1, 5535.

[8] A. Yella, R. Humphry-Baker, B. F. E. Curchod, N. Ashari Astani, J. Teuscher, L. E. Polander, S. Mathew, J. E. Moser, I. Tavernelli, U. Rothlisberger, M. Grätzel, M. K. Nazeeruddin, J. Frey, Chem. Mater. 2013, 25, 2733.

[9] J.-H. Yum, T. W. Holcombe, Y. Kim, K. Rakstys, T. Moehl, J. Teuscher, J. H. Delcamp, M. K. Nazeeruddin, M. Grätzel, Sci. Rep. 2013, 3, 2446.

[10] P. Gao, H. N. Tsao, C. Yi, M. Grätzel, M. K. Nazeeruddin, Adv. Energy Mater. 2014, 4, 1301485.

[11] J. H. Delcamp, A. Yella, T. W. Holcombe, M. K. Nazeeruddin, M. Grätzel, Angew. Chem. Int. Ed. 2013, 52, 376.

[12] M. Urbani, M. Grätzel, M. K. Nazeeruddin, T. Torres, Chem. Rev. 2014, 114, 12330.

[13] S. Mathew, A. Yella, P. Gao, R. Humphry-Baker, B. F. E. Curchod, N. Ashari-Astani, I. Tavernelli, U. Rothlisberger, M. K. Nazeeruddin, M. Grätzel, Nat. Chem. 2014, 6, 242.

[14] T. Bessho, S. M. Zakeeruddin, S. M. Yeh, C. Y. Diau, M. Grätzel, Angew. Chem. Int. Ed. 2010, 49, 6646.

[15] G. de la Torre, C. G. Claessens, T. Torres, Chem. Commun. 2007, 2000.

[16] J. Mack, N. Kobayashi, Chem. Rev. 2011, 111, 281.

[17] M. Ince, J.-H. Yum, Y. Kim, S. Mathew, M. Grätzel, T. Torres, M. K. Nazeeruddin, J. Phys. Chem. C 2014, 118, 17166. 
[18] P. Gao, M. Grätzel, M. K. Nazeeruddin, Energy Environ. Sci. 2014, 7, 2448.

[19] C. C. Stoumpos, C. D. Malliakas, M. G. Kanatzidis, Inorg. Chem. 2013, 52, 9019.

[20] V. D'Innocenzo, G. Grancini, M. J. P. Alcocer, A. R. S. Kandada, S. D. Stranks, M. M. Lee, G. Lanzani, H. J. Snaith, A. Petrozza, Nat. Commun. 2014, 5, 3586 .

[21] G. Giorgi, J.-I. Fujisawa, H. Segawa, K. Yamashita, J. Phys. Chem. Lett. 2013, 4, 4213.

[22] G. Xing, N. Mathews, S. Sun, S. S. Lim, Y. M. Lam, M. Grätzel, S. Mhaisalkar, T. C. Sum, Science 2013, 342, 344.

[23] Q. Dong, Y. Fang, Y. Shao, P. Mulligan, J. Qiu, L. Cao, J. Huang, Science 2015, 347, 967.

[24] G. Xing, N. Mathews, S. S. Lim, N. Yantara, X. Liu, D. Sabba, M. Grätzel, S. Mhaisalkar, T. C. Sum, Nat. Mater. 2014, 13, 476.

[25] A. Kojima, K. Teshima, Y. Shirai, T. Miyasaka, J. Am. Chem. Soc. 2009, 131, 6050.

[26] D. B. Mitzi, Chem. Mater. 2001, 13, 3283.

[27] M. M. Lee, J. Teuscher, T. Miyasaka, T. N. Murakami, H. J. Snaith, Science 2012, 338, 643.

[28] J. Burschka, N. Pellet, S.-J. Moon, R. HumphryBaker, P. Gao, M. K. Nazeeruddin, M. Grätzel, Nature 2013, 499, 316.

[29] M. Liu, M. B. Johnston, H. J. Snaith, Nature 2013, 501, 395.

[30] Q. Chen, H. Zhou, Z. Hong, S. Luo, H.-S Duan, H.-H. Wang, Y. Liu, G. Li, Y. Yang, J. Am. Chem. Soc. 2014, 136, 622.

[31] Z. Xiao, C. Bi, Y. Shao, Q. Dong, Q. Wang, Y. Yuan, C. Wang, Y. Gao, J. Huang, Energy Environ. Sci. 2014, 7, 2619.

[32] S. Ryu, J. H. Noh, N. J. Jeon, Y. C. Kim, W. S. Yang, J. Seo, S. Il Seok, Energy Environ. Sci. 2014, 7, 2614.

[33] Y. Zhou, M. Yang, W. Wu, A. L. Vasiliev, K. Zhu, N. P. Padture, J. Mater. Chem. A 2015, DOI 10.1039/C5TA00477B.

[34] A. Mei, X. Li, L. Liu, Z. Ku, T. Liu, Y. Rong, M. Xu, M. Hu, J. Chen, Y. Yang, M. Grätzel, H. Han, Science 2014, 345, 295.

[35] N. Pellet, P. Gao, G. Gregori, T. Y. Yang, M. K. Nazeeruddin, J. Maier, M. Grätzel, Angew. Chem. Int. Ed. 2014, 53, 3151.

[36] O. Malinkiewicz, A. Yella, Y. H. Lee, G. M. M. Espallargas, M. Grätzel, M. K. Nazeeruddin, H. J. Bolink, Nat. Photonics 2014, 8, 128.

[37] A. Dualeh, P. Gao, S. Il Seok, M. K Nazeeruddin, M. Grätzel, Chem. Mater. 2014, 26, 6160 .

[38] A. Dualeh, T. Moehl, N. Tétreault, J. Teuscher, P. Gao, M. K. Nazeeruddin, M. Grätzel, ACS Nano 2014, 8, 362.

[39] A. Dualeh, N. Tétreault, T. Moehl, P. Gao, M. K. Nazeeruddin, M. Grätzel, Adv. Funct. Mater. 2014, 24, 3250.

[40] P. Qin, A. L. Domanski, A. K. Chandiran, R. Berger, H.-J. Butt, M. I. Dar, T. Moehl, N. Tetreault, P. Gao, S. Ahmad, M. K. Nazeeruddin, M. Grätzel, Nanoscale 2014, 6, 1508.

[41] M. I. Dar, N. Arora, P. Gao, S. Ahmad, M. Grätzel, M. K. Nazeeruddin, Nano Lett. 2014 14, 6991 .
[42] L. Etgar, P. Gao, P. Qin, M. Grätzel, M. K. Nazeeruddin, J. Mater. Chem. A 2014, 2, 11586.

[43] E. Edri, S. Kirmayer, M. Kulbak, G. Hodes, D. Cahen, J. Phys. Chem. Lett. 2014, 5, 429.

[44] E. Edri, S. Kirmayer, A. Henning, S. Mukhopadhyay, K. Gartsman, Y. Rosenwaks, G. Hodes, D. Cahen, Nano Lett. 2014, 14, 1000.

[45] N. J. Jeon, J. Lee, J. H. Noh, M. K. Nazeeruddin, M. Grätzel. S. Il Seok, J. Am. Chem. Soc. 2013 , 135, 19087.

[46] T. Krishnamoorthy, F. Kunwu, P. P. Boix, H. Li, T. M. Koh, W. L. Leong, S. Powar, A. Grimsdale, M. Grätzel, N. Mathews, S. G. Mhaisalkar, J. Mater. Chem. A 2014, 2, 6305.

[47] H. Li, K. Fu, A. Hagfeldt, M. Grätzel, S. G. Mhaisalkar, A. C. Grimsdale, Angew. Chem. Int. Ed. 2014, 53, 4085.

[48] J. H. Heo, S. H. Im, J. H. Noh, T. N. Mandal, C.-S. Lim, J. A. Chang, Y. H. Lee, H. Kim, A Sarkar, M. K. Nazeeruddin, M. Grätzel, S. Il Seok, Nat. Photonics 2013, 7, 486.

[49] B. Cai, Y. Xing, Z. Yang, W.-H. Zhang, J. Qiu, Energy Environ. Sci. 2013, 6, 1480.

[50] Y. S. Kwon, J. Lim, H.-J. Yun, Y.-H. Kim, T. Park, Energy Environ. Sci. 2014, 7, 1454.

[51] J. A. Christians, R. C. M. Fung, P. V Kamat, J. Am. Chem. Soc. 2014, 136, 758.

[52] P. Qin, S. Paek, M. I. Dar, N. Pellet, J. Ko, M. Grätzel, M. K. Nazeeruddin, J. Am. Chem. Soc. 2014, 136, 8516.

[53] P. Qin, N. Tetreault, M. I. Dar, P. Gao, K. L. Mccall, S. R. Rutter, S. D. Ogier, N. D. Forrest, J. S. Bissett, M. J. Simms, A. J. Page, R. Fisher, M. Grätzel, M. K. Nazeeruddin, Adv. Energy Mater. 2014, 197, DOI: 10.1002/ aenm.201400980.

[54] P. Qin, H. Kast, M. K. Nazeeruddin, S. M Zakeeruddin, A. Mishra, P. Bauerle, M. Grätzel, Energy Environ. Sci. 2014, 7, 2981.

[55] M. K. Nazeeruddin, F. Ramos, M. Ince, M. Urbani, A. Abate, M. Grätzel, S. Ahmad, T. Torres, Dalton Trans. 2015, DOI 10.1039/ C5DT00396B.

[56] P. Qin, S. Tanaka, S. Ito, N. Tetreault, K. Manabe, H. Nishino, M. K. Nazeeruddin, M Grätzel, Nat. Commun. 2014, 5, 3834 .

[57] Y. Lee, J. Kwon, E. Hwang, C.-H. Ra, W. J. Yoo, J.-H. Ahn, J. H. Park, J. H. Cho, Adv. Mater 2015, 27, 41 .

[58] Z.-K. Tan, R. S. Moghaddam, M. L. Lai, P. Docampo, R. Higler, F. Deschler, M. Price, A. Sadhanala, L. M. Pazos, D. Credgington, F. Hanusch, T. Bein, H. J. Snaith, R. H. Friend, Nat. Nanotechnol. 2014, 9, 687 .

[59] T. Moehl, J. H. Im, Y. H. Lee, K. Domanski, F. Giordano, S. M. Zakeeruddin, M. I. Dar, L.-P. Heiniger, M. K. Nazeeruddin, N.-G. Park, M. Grätzel, J. Phys. Chem. Lett. 2014, 5, 3931

[60] S. Lamansky, P. Djurovich, D. Murphy, F. Abdel-Razzaq, R. Kwong, I. Tsyba, M. Bortz, B. Mui, R. Bau, M. E. Thompson, Inorg. Chem. 2001, 40, 1704.

[61] H. Yersin, 'Highly Efficient OLEDs with Phosphorescent Materials', Wiley-VCH, Weinheim, 2008.

[62] M. K. Nazeeruddin, R. Humphry-Baker, D
Berner, S. Rivier, L. Zuppiroli, M. Grätzel, J. Am. Chem. Soc. 2003, 125, 8790.

[63] H. J. Bolink, L. Cappelli, E. Coronado, M. Grätzel, M. K. Nazeeruddin, J. Am. Chem. Soc. 2006, 128,46

[64] H. J. Bolink, L. Cappelli, E. Coronado, M. Grätzel, E. Ortí, R. D. Costa, P. M. Viruela, M. K. Nazeeruddin, J. Am. Chem. Soc. 2006, 128 , 14786 .

[65] E. Baranoff, S. Suarez, P. Bugnon, H. J. Bolink, C. Klein, R. Scopelliti, L. Zuppiroli, M. Grätzel, M. K. Nazeeruddin, ChemSusChem 2009, 2, 305.

[66] H. J. Bolink, F. De Angelis, E. Baranoff, C. Klein, S. Fantacci, E. Coronado, M. Sessolo, K. Kalyanasundaram, M. Grätzel, M. K. Nazeeruddin, Chem. Commun. 2009, 4672.

[67] F. Kessler, R. D. Costa, D. Di Censo, R. Scopelliti, E. Ortí, H. J. Bolink, S. Meier, W. Sarfert, M. Grätzel, M. K. Nazeeruddin, E. Baranoff, Dalton Trans. 2012, 41, 180.

[68] D. Tordera, M. Delgado, E. Ortí, H. J. Bolink, J. Frey, M. K. Nazeeruddin, E. Baranoff, Chem. Mater. 2012, 24, 1896.

[69] D. Tordera, A. Pertegás, N. M. Shavaleev, R. Scopelliti, E. Ortí, H. J. Bolink, E. Baranoff, M. Grätzel, M. K. Nazeeruddin, J. Mater. Chem. 2012, 22, 19264.

[70] N. M. Shavaleev, F. Monti, R. D. Costa, R. Scopelliti, H. J. Bolink, E. Ortí, G. Accorsi, N. Armaroli, E. Baranoff, M. Grätzel, M. K. Nazeeruddin, Inorg. Chem. 2012, 51, 2263.

[71] E. D. Baranoff, S. B. Meier, W. Sarfert, J. Junquera-Hernandez, M. Delgado, D. Tordera, E. Orti, H. J. Bolink, F. Kessler, R. Scopelliti, M. Grätzel, M. K. Nazeeruddin, J. Mater. Chem. C 2013, 2, 58 .

[72] N. M. Shavaleev, R. Scopelliti, M. Grätzel, M. K. Nazeeruddin, A. Pertegás, C. RoldánCarmona, D. Tordera, H. J. Bolink, J. Mater. Chem. C 2013, 1, 2241 .

[73] D. Tordera, J. J. Serrano-Pérez, A. Pertegás, E. Ortí, H. J. Bolink, E. Baranoff, M. K. Nazeeruddin, J. Frey, Chem. Mater. 2013, 25, 3391.

[74] F. Kessler, Y. Watanabe, H. Sasabe, H. Katagiri, M. K. Nazeeruddin, M. Grätzel, J. Kido, J. Mater. Chem. C 2013, 1, 1070.

[75] M. G. Walter, E. L. Warren, J. R. McKone, S W. Boettcher, Q. Mi, E. A. Santori, N. S. Lewis, Chem. Rev. 2010, 110, 6446.

[76] T. R. Cook, D. K. Dogutan, S. Y. Reece, Y. Surendranath, T. S. Teets, D. G. Nocera, Chem. Rev. 2010, 110, 6474

[77] J. Suntivich, K. J. May, H. A. Gasteiger, J. B. Goodenough, Y. Shao-Horn, Science 2011, 334, 1383.

[78] M. Schreier, P. Gao, M. T. Mayer, J. Luo, T. Moehl, M. K. Nazeeruddin, S. D. Tilley, M. Gr, M. Grätzel, Energy Environ. Sci. 2015, 8, 855.

[79] J. Luo, J.-H. Im, M. T. Mayer, M. Schreier, M. K. Nazeeruddin, N.-G. Park, S. D. Tilley, H. J. Fan, M. Gratzel, Science 2014, 345, 1593. 